\title{
POLITICAL AND ECONOMIC TRANSITION OF OTTOMAN SOVEREIGNTY FROM A SOLE MONARCH TO NUMEROUS OTTOMAN ELITES, 1683-1750s
}

\author{
BIROL GÜNDOĞDU \\ Justus-Liebig-Universität Gießen \\ Historisches Institut, Osteuropäische Geschichte \\ Otto-Behaghel-Str. 10, Haus D Raum 205, 35394 Gießen, Deutschland \\ e-mail: birolgundogdu@gmail.com
}

\begin{abstract}
The aim of this paper is to reveal the transformation of the Ottoman Empire following the debacles of the second siege of Vienna in 1683. The failures compelled the Ottoman state to change its socioeconomic and political structure. As a result of this transition of the state structure, which brought about a so-called "redistribution of power" in the empire, new Ottoman elites emerged from 1683 until the $1750 \mathrm{~s}$. We have divided the above time span into three stages that will greatly help us comprehend the Ottoman transition from sultanic authority to numerous autonomies of first Muslim, then non-Muslim elites of the Ottoman Empire. During the first period (1683-1699) we see the emergence of Muslim power players at the expense of sultanic authority. In the second stage (1699-1730) we observe the sultans' unsuccessful attempts to revive their authority. In the third period (1730-1750) we witness the emergence of non-Muslim notables who gradually came into power with the help of both the sultans and external powers. At the end of this last stage, not only did the authority of Ottoman sultans decrease enormously, but a new era evolved where Muslim and non-Muslim leading figures both fought and co-operated with one another for a new distribution of wealth in the Ottoman Empire.
\end{abstract}

Key words: Ottoman Empire, malikane system, sultanic authority, non-Muslim elites, Phanariotes, westernisation.

\section{A New Beginning in a Traditional Empire (1683-1699)}

Although the Ottoman Empire had already lagged far behind the other major European powers long before the second siege of Vienna in 1683, it was not until the humiliating treaty of 1699 that the Ottomans began to think comprehensively about the question of what had gone wrong in the empire and to develop sustainable solutions for the problems it had been experiencing for many decades (Lewis 2002, p. 17). This catastrophic defeat of the empire at the hands of its old Christian enemies, among them 
the renewed Russian state of Peter the Great, essentially and dramatically forced the Ottomans to change their ancient (kadim) structure and traditional system, and opened the way to the new Muslim elites who were not only quite different from earlier leading figures, but were also eager to challenge the empire, if need be, for the sake of their newly established power within the state.

Not long after the Ottoman defeat of 1683 in Vienna the empire lost substantial territories in the Balkans, which in a way marked the end of further Ottoman westward expansion. Following the final defeat at the hands of Prince Eugene of Savoy at Zenta in 1697, the Ottomans were forced to acknowledge defeat and permanently ceded almost all of Hungary, Transylvania, Croatia and Slovenia to Austria. Even though they were far from the glorious days of being a real rival to the Ottoman Empire, the Venetians also took full possession of Dalmatia, the Morea and some of the Aegean islands. Moreover, the Ottoman-Russian War, which had begun in 1686, not only ended with the Russian capture of the crucial port of Azov in 1693, but also proved the power of Russia as a newly emerging enemy in the north. Last but not least, Poland, which had helped the Habsburgs against the Ottoman imperial army at a very crucial moment in the war, took possession of southern Ukraine from the Ottoman Empire.

The Ottoman ideology of a superior Islamic empire was evidently shattered as a result of sixteen years of defeat at the hands of Christians. Unsurprisingly, this was not only a tremendous blow to the Ottoman Empire and its long rightful claim of being a world empire, but also to the imperial ideology on its own. It was in fact the first occasion that the Ottomans not only officially accepted the mediation of neutral European states, but also admitted to the heavy defeat of the Ottoman Empire. In the end, Ottoman unilateral diplomacy of earlier centuries was replaced with more moderate diplomatic and multilateral relations with the European powers. Consequently, it became now more and more obvious that "the Turkish menace" was a thing of the past, particularly from the second half of the 18th century onwards.

Even before the immediate loss of international prestige, however, domestic policy in the empire began to be determined by those high-ranking officials who had either forged an alliance through marrying a princess of the Ottoman dynasty, or maintained authority simply due to their personal charisma. Moreover, the vizier and the pasha, who were responsible for providing their supporters with employment, protection, training and the right contacts, reserved most official appointments for their closest cohorts. ${ }^{1}$ To give but one prominent example, in 1656, Mehmed IV had already given over executive power to Köprülü Mehmed Pasha who became de facto ruler of the Ottoman Empire with the help of members of his household. Particularly important is here the fact that the diversion of executive power to the vizier or pasha, and the new power arrangement in its wake, were kept intact long after Köprülü Mehmed Pasha died in 1661 (Abou-El-Haj 1984, p. 88).

${ }^{1}$ Abou-El-Haj argues in his book that toward the end of the 17th century, about half of the central and provincial administrators were members of one pasha's household who were either raised and trained by, or attached to viziers and pashas (Abou-El-Haj 1984, p. 9). 
Traditionally (or at least theoretically), state officers of palace origin who held the highest positions in the empire were to be exclusively appointed by an "absolute ruler". All their prerogatives and privileges relied upon none but the sultan himself and with the accession of his successor, state appointees simply lost all their rights unless they were renewed by the new ruler. Following 1683, however, the power of the imperial Ottoman household was significantly weakened. Now, it was not the sultan but the grand viziers and their households, as well as other leading Muslim figures that began to decide who would fill vacancies in the highest positions of the empire. Namely, the chance to obtain a high position in the Ottoman Empire began to depend on a relationship with these new figures, rather than the sultans' favour. Thus, immediate family members of viziers or pashas, including their brothers, sons-in-law and other relatives, became favoured candidates for the vacancies available in state administration. Relatives of Köprülü Mehmed Pasha, who got the highest positions in state administration during and after his rule, are prime examples of this new mode of governance. To be precise, in the forty-seven years following Köprülü Mehmed Pasha, the Ottoman grand vizierate was held for thirty-eight years by members of the Köprülü family including the direct descendants of Mehmed Pasha, Köprülü Ahmed and Mustafa Pasha; his nephew Amcazade Hüseyin Pasha; his son-in-law Kara Mustafa Pasha; and other members of the Köprülü family, such as Kara Ibrahim, Köprülü Mehmed Pasha and his son-in-law Abaza Siyavuş (Abou-El-Haj 1974, pp. 443-444).

These members of the Köprülü family, who had acquired the positions of the highest dignitaries in the empire between 1683 and 1703, were powerful and confident enough to overthrow the Ottoman sultan who fought against their domination following the failed siege of Vienna in 1683. That is, with the "Edirne Event" of 1703, the Köprülü family made an attempt to annihilate its opponents Mustafa II (1695-1703) and Fethullah Efendi who were struggling to eliminate (or at least restrain) the power of the Köprülü households. As a result, a military uprising was triggered in Istanbul, which not only deposed Sultan Mustafa but also took the life of Feyzullah Efendi in 1703. Abou-El-Haj comes to the conclusion that "the growing power of the vezir and paşa households, here demonstrated by the Köprülü and its satellite kapilar, made them equal to the supreme task of creating and deposing Sultans" (Abou-El-Haj 1974, p. 446).

To be more precise, after signing the Treaty of Karlowitz in 1699 and that of Istanbul in 1700, Mustafa strove to regain traditional sultanic power over the leading pasha households. However, reasserting and solidifying his threatened position required Mustafa II's dependence on his former mentor, Feyzullah Efendi, who represented the ulema class (i.e. learned religious class) at that time. In this case, even if he had not been deposed in the coup attempt of 1703, the sultan's power and stature would have been considerably diminished since he would not have the freedom to manage the state without interference from an another interested party, i.e., the ulema. Consequently, by 1703 , the sultan lost his traditional claim to absolute rule. The problem is even further complicated by the contradiction between the Ottoman theory of power (according to which none but the sultan could claim to be an absolute ruler) and the reality that had evolved by the end of the 17th century. On balance, 
the Ottoman debacle of 1683-1699 and the subsequent "Edirne Event" brought about a period where neither the sultan nor the Ottoman dynasty itself was indispensable or even very significant in the decision-making of 18 th-century Ottoman society. ${ }^{2}$

In reality, vizier and pasha households were not that different from those of the sultans. That is to say, viziers, pashas and sultans all acquired slaves with specific skills for use in strengthening their position within the state apparatus. In theory, of course, the sultan remained the only ruler who had the right and power to appoint anyone to any position in the empire. But in practice, his power was not much different from those viziers or pashas who sought to reserve the best positions for their own men. The number of these burgeoning households was not truly significant until the third quarter of the 17th century. However, Abou-El-Haj's studies clearly prove that in the period between 1683 and 1703, other than the grand vizierate, important state positions were frequently filled with more members of the vizier's and pasha's households than those of the sultan's household, who had traditionally graduated from palace schools in the past (Abou-El-Haj 1974, p. 443).

At this juncture, during and following the wars of $1683-1699$, it is quite reasonable to question whether the sultan retained any ability to influence state affairs or potency to press his will over these increasingly powerful pasha households. Suffice it to say that by this time, Ottoman sultans were far from being seen as de facto rulers of the empire, let alone as universal absolute rulers.

Although the right to rule of the Ottoman dynasty was not really questioned at this stage, the sultan was left powerless in practice. The "Edirne Event" totally guaranteed that if the sultan wished to have any effect in the empire, he had to take into consideration the interested parties and ensure their support in his policies (Abou-ElHajj 1984, p. 91). That is, the relationship between the sultan and the pashas and their households became one of mutuality and interdependence, especially during times of trouble when the sultans were in desperate need of their economic and military support. From this point onward, the sultan was no longer in a position to make unilateral proclamations or declarations. Negotiation defined the scope of sultanic power and developed a new concept of state function in which the sultan was turned to be nothing but primus inter pares - as it once had been in the earliest part of Ottoman history (circa. 1301-1453). ${ }^{3}$ At this point, Abou-El-Haj argues that the "Edirne Event"

${ }^{2}$ Uzunçarş11 mentions that as the rebels of 1703 marched to Edirne for the purpose of deposing Mustafa II, they were even thinking of overthrowing the Ottoman dynasty in favour of either the Genghis Khanid dynasty or the Ibrahimzades (Uzunçarş11 1956, pp. 33-34). Abou-El-Haj also argues that a rebellion like that of 1703 would provide an opportunity either to reassert one's power or to maintain existing control. This is a struggle that might have been launched against any interested parties, the Ottoman dynasty itself included (Abou-El-Haj 1984, p. 10).

${ }^{3}$ Erdenen notes that following the "Edirne Event" and the deposition of Mustafa II, the rebels and their supporters obtained the highest positions in state administration and Ahmed III was no longer able to trust even his guards (bostancis), who were supposed to protect the Sultan against any danger. As a result, he dismissed 700 bostancis from the palace and replaced them with new devşirmes till the end of his reign. It was only by doing so, Erdenen argues, that Ahmed III was able to create a staff on which he could rely (Erdenen 2003, pp. 19-20). In a sense, as a response to 
of 1703 - which had constrained the power of the Ottoman household and elevated that of the pasha households - might have led to the emergence of provincial powers in the 18th century (Abou-El-Haj 1974, p. 447). More importantly, in opposition to the Ottoman style at the time, monarchs in Europe were not only concentrating state power in their own hands, but also taking the power away from state elites or notables (Quataert 2005, p. 43).

\section{The Malikane System and the Economic Transformation of the Ottoman Empire after 1683}

Before analysing what happened after the Treaty of Karlowitz one should answer the question of what this long war and the subsequent treaty brought to the Ottoman Empire and how this related to the emergence of new Muslim elites. To start with, the sixteen-year war devastated the existent Ottoman system which had already been under threat throughout the 17th century. The introduction of the lifelong tax farm system (malikane), indicating a desperate and urgent need of cash, is of significance here. ${ }^{4}$ Özvar's study of the malikane system including a period of thirty months immediately after it was implemented in 1695 clearly indicates that it was widely applied in many Ottoman cities (Özvar 2003, pp. 133-146). In a similar vein, Uzunçarş1l (1956, p. 438) and Zarinebaf (2005, p. 39) also support the same fact that in the second half of the 18th century, a substantial number of malikanes had been held by Ottoman princesses in many regions that played a great role in the history of the empire.

Unsurprisingly, the continuing wars against the Holy League triggered a devastating financial crisis and forced the state to implement a new economic policy at the expense of the old system. Accordingly, the Ottoman Empire had to introduce this new tax farming system in 1695 in order to raise more cash which was needed to cover exorbitant expenses of the prolonged wars. The emergence of ayan (Muslim provincial magnates) should be seen in this context. Mehmet Genç's study, based on the material of the Prime Minister's Ottoman Archives, gives some clear evidence for this dramatic reality. He states that the deficit of the Ottoman budget in 1669-1670 was 44,677,388 akçes (silver coin, asper) and by 1690-1691, it had multiplied approximately six times to $247,116,957$ akçes (Genç 2002, p. 104). Urgently seeking income to support on-going military campaigns, the state was forced to accept a new form of tax contract, i.e. the malikane, which changed the state infrastructure irrevocably and forever. Unlike the iltizams, which were short-term farming of taxes, ${ }^{5}$ malikanes

the threat of the increasingly powerful pasha households, he intended to create his own households that were of course much less powerful than their predecessors' in the 16th century.

${ }^{4}$ Cezar argues that the introduction of the malikane system was the first radical change in the Ottoman fiscal system. Before that, the empire endeavoured to keep the traditional system, making minor adjustments if needed (Cezar 1986, p. 33).

${ }^{5}$ Iltizams were usually given for three years, and afterwords their owners lost all of their rights. They did not even have unlimited or uncontrollable privileges of ownership within the set period. To give but one example, if for one reason or another certain incomes of an iltizam increased, 
were assigned for life (ber vech-i mâlikâne) on condition that the owners paid a large initial payment (muaccele), and regular annual payments (mal) thereafter. More importantly, in return for paying this muaccele beforehand malikane owners also gained important privileges and immunities, which, in a sense, turned state lands into private properties, as we will see in greater detail below. Salzmann not only argues that malikane facilitated privatisation of state revenue, but also called it the "fiscal privatisation" of the Ottoman Empire. Nonetheless, this privatisation does not necessarily mean that the malikane holders soon started to invest their money in fields other than state lands, as had frequently been the case in Europe. Instead, obtaining tax revenues was much more lucrative than making an investment in any other enterprise of the Ottoman Empire. Ironically enough, establishment of the malikane system is therefore given as the very reason why the Ottomans were still able to keep control in the provinces long after its power had faded away there. After all, the perpetuation of the state remained important to the malikane holders, who continued to earn substantially under this new system to the detriment of state sovereignty and interests. ${ }^{6}$

The role of the malikane system within the Ottoman Empire increased dramatically from 1695 to 1774 . To be exact, the number of mukataas registered as malikane multiplied by 220 to 680 . As a result, the total revenue acquired from the new system provided more income to the state toward the end of the 18th century $(375,171,600$ akçes instead of 199,838,944 akçes i.e., 88\%). In the same period, the number of the tax revenues (vergi kalemi) sold as malikane increased from 115 to 514 (347\%), so the Ottoman state acquired 161,619,480 akçes income instead of the former 10,752,920 akçes (1400\%). In 1697-1698 malikane revenues constituted only 5.3\% of the total income, but in 1774 this increased to $43 \%$, a clear indicator of the system's ascendant importance, from its first implementation to 1774 (Genç 2002, p. 117). Sahillioğlu's study further proves that the income and expenditure of the Ottoman treasury were continuously on the increase between 1683 and 1740 (Sahillioğlu 1999, pp. 65-82). When we bring Genç and Sahillioğlu's arguments together, the impact of the malikane system upon the Ottoman economy becomes almost indisputable.

Similar to the esham (a form of long-term domestic borrowing), which was initiated following the Ottoman-Russian Wars of 1768-1774 once again due to Ottoman economic bankruptcy, the malikane was an attempt to cope with the late 17th-century crisis that had reached its apogee with the sixteen-year wars of 1683-1699. Yet, when we take into consideration the hard conditions the empire had experienced during these war years, at first glance, the malikane does not really seem to be a radical change in Ottoman structure. After all, the Ottomans had been working with the iltizam

other entrepreneurs kept the right to offer more money in return for this iltizam before the end of the three years. In that case, either the owner of this iltizam had to contract to pay more, or lost all of his rights coming from the iltizam before the end of the prescribed time. Basically, the iltizam could have been transferred to someone else who offered more money to the state in return. See Özvar (2003, pp. 3, 20-21).

Salzmann (1993, pp. 393-423) convincingly argues that the Ottoman Empire succeeded in keeping political loyalty intact by providing significant investment opportunity for interested parties from either the administration or the upper classes. The continued material interest resulted in continuous political loyalty to the Ottomans even long after they had lost most of their power. 
system for centuries, and in many respects, the malikane was relatively similar to this previous application. In addition to eliminating problems of the iltizam system, which had been rightly blamed for being a huge financial burden to the reaya (members of the tax-paying population) and for decreasing productivity of Ottoman lands in the long run, from the outset the malikane system could even be thought to provide better protection for both these lands and the Ottoman reaya.

However, when we look closely at the malikane system and what it brought to the Ottoman Empire, its great influence on the evolution of a new Ottoman system - which changed the state structure once and for all - cannot be described as a simple modification of the iltizam system. For instance, unlike the iltizam system of early decades, in the malikane system, the Ottomans targeted small-scale entrepreneurs to a great extent (Genç 2002, p. 107). ${ }^{7}$ That is, the state intended to sell small properties at auction or to divide large properties into smaller parcels (mukataas, i.e. tax farm), so that even small entrepreneurs could take their place in this new system. ${ }^{8}$ No doubt there were a substantial number of malikane owners who were members of the military class or had a close affiliation with it, or other leading Muslim subjects of more modest origin (such as the ayan). Unsurprisingly, therefore, the malikane system reached a wider variety of people, including the non-military subjects of the empire. As a result, now we have not only members of the military class, i.e. pasha households (whose property and future were no longer directly dependent on the sultans), but also new Muslim elites who were eager to construct political and economic bases in the Ottoman provinces as well as those big cities that were relatively far from the direct influence of Istanbul.

The privileges and prerogatives of the malikane system exceeded, beyond comparison, those of the iltizam system. To give but one example, upon their death malikane holders were seemingly not allowed to bequeath the malikanes to their heirs. Nonetheless, heirs of malikane holders still enjoyed preferential rights of bidding on properties, which more or less left the transfer of the malikane lands in the hands of the same family. In other words, malikane owners had the power and right to leave their lands to both male and female heirs as if these lands were mülk (private property) or religious endowments. Suceska's example of the Rizvanbegoviç family in Bosnia clearly proves the fact that as malikane holders, members of this family easily succeeded in keeping malikane lands under their own control and bequeathing malikane properties of all kind to their children, spouse(s) and other heirs for more than a hundred years. In the end, malikane holders emerged as privileged groups in both political and social realms of the region. Such families whose power relied upon the

${ }^{7}$ Indeed, as it is understood from Özvar's studies on the malikane system, the Ottomans first targeted small entrepreneurs rather than big ones, and the system became widespread all over the empire in no time. To be exact, just two years after implementation, the malikane hass and ocaklik mukataas started to be included within the system. It was only after this that the state started to make a huge income from the malikane system (Özvar 2003, pp. 29-50).

${ }^{8}$ Özvar's statistics concerning the numbers of shared malikane showed that for the years between 1695 and 1697, it was far from being negligible. Accordingly, 37\% of all malikane sold during that period were owned by two or more owners. Another noteworthy point in this study is that, again, 37\% of all shared malikanes were shared by fathers and sons (Özvar 2003, pp. 84-85). 
malikane system, Suceska concludes, created their own feudal system within the empire, which later became the source of anarchy throughout the entire 18th century (Suceska 1985, p. 281).

Moreover, the malikane owners had total freedom to put the lands on the market (kasr-i yed) as if they were not miri lands (state owned lands). As such, unlike in previous centuries, for the first time in Ottoman history state lands to a large extent became a commercial commodity from which one could benefit to the detriment of state interests. ${ }^{9}$ A specific feature of high importance in the malikane system that largely contributed to the state's loss of full and rightful possession of lands is that as long as the malikane owners paid predetermined taxes on time, the Ottoman Empire guaranteed that the malikane tax would not be increased against the malikane owners' will. Consequently, tax income could only be increased by $10 \%$ over the whole 18 th century, while real prices increased by four times (Genç 2002, p. 27). In particular, when we take the high inflation rate of the 18th-century Ottoman Empire into consideration, this guarantee obviously became a great burden for the treasury and forced the Ottomans to find other forms of income in order to pay the exorbitant military and social expenses of the empire which derived its main revenues from lands. ${ }^{10}$

Last but not least, other than kadis - who were the head of legal courts in the Ottoman Empire - only the malikane owners had the benefit of full immunity from administrative interference [as it is often written in Ottoman sources: "mefrûzü'lkadem ve maktûü'l-kadem min külli'l-vücûh serbesiyet üzere tasarruf etmesi içün" or "cümle tekaliften ve mezalimden serbestiyet üzere tasarruf" (Özvar 2003, p. 21)]. Furthermore, the malikane holders functioned as policemen as well as administrators of the region(s) under their control. More importantly, however, they were not only responsible for collecting the usual taxes, but also for gathering other taxes including resm and harâç as well as some extraordinary taxes such as avartz-i divaniye and tekâlif-i örfiye (Suceska 1985, p. 279). On balance, İnalckk comes to the conclusion that with the malikane system lands "became virtually like property, leasers actual landlords, and peasants their tenants. In other words, the whole class of lease-holders (eshâb-i mukâtaa) now intervened between the state and peasants" (İnalcık 1983, p. 112).

Besides the obvious economic factors, the malikane system also brought about significant social and institutional changes in the Ottoman Empire. No wonder, the malikane owners were often members of the military class in Istanbul or at least had

${ }^{9} \mathrm{We}$ come across a large number of examples where the malikane owners or their heirs misused this right and made large amounts of money to the detriment of the Ottoman treasury. For example, according to the contract the state kept the right to resell malikanes after the death of their leasers (mahlûl). But often the state was not informed about mahlûl, and the lands were either sold to another leaser or used by the heirs of the dead malikane holders. Later, the Ottomans had to take measures to prevent such misusages (Genç 2002, p. 108).

${ }^{10}$ Yavuz Cezar claims that being unable to discover the mahlûl on time was the very grounds for the state decision to increase the malikane lands in order to meet with the expenses of the time. As a result, more and more lands were sold at auction and the malikanes became quite widespread throughout the whole empire (Cezar 1986, pp. 34, 72). 
a close connection with the palace. ${ }^{11}$ Consequently, the line between the members of the askeri (military) class and the reaya began to blur, since buying malikane lands also made the askeri landowners responsible for paying tax to the state as if they were reaya. More importantly though, they usually preferred to subcontract their malikane lands to second or even third parties called mültezims/mütesellims. In that respect, the malikane system did not abrogate the iltizam system altogether, but rather it was integrated into the iltizam system, as will be seen below (Genç 2002, p. 111).

Relations between the malikane holders and subcontractors - usually local notables - were not always harmonious. These mültezims, who were the most powerful and influential people of their regions, used the malikane lands to increase their influence over the reaya and they constituted the powerful ayan of the 18th-century Ottoman Empire in the course of time. By means of these subcontractual positions given to the ayan first with the iltizam system, and then more elaborately with the malikane system, influential local families not only acquired an important source of economic power, but also had the opportunity to reinforce their influence in the provinces. ${ }^{12}$ As İnalc1k argues, unlike the ayan of earlier centuries, the ayan of the 18th century were given an opportunity to be part of the Ottoman ruling class, since they began to take advantages of some official titles, such as mütesellim (Inalc1k 1977, p. 32). ${ }^{13}$ In the long run, starting from the end of the 17th century, local notables were appointed to official positions with the new titles including kapıcıbaşı, ağa, bey, which had been not only extremely uncommon among them in previous years, but also a privilege exclusively given for members of the military class of kapıkulu origin. This is interpreted as "the direct delegation of sultan's authority" (İnalckk 1977, p. 40). At this point, we now have members of pasha households and a substantial number of local notables given the privileges and prerogatives previously held only by the military class. Unlike the earlier askeri class, however, they did not possess a burning desire to support the sultan and his policies, nor did they hesitate to bolster other interested parties at the expense of state stability.

Throughout the 18th century the ayan made themselves indispensable to the state by means of providing whatever the state needed, especially during times of trouble and turmoil. The Ottoman experience at the end of the 1683-1699 wars and

${ }^{11}$ According to one estimation, $36 \%$ of the value of regional holdings in the Balkans, $17 \%$ of those in Aleppo, and 5\% of those in Anatolia were held by Ottoman high dignitaries in the year of 1703. See Salzmann (forthcoming). On the other hand, Genç argues that according to a decree (KK, $5040,5)$ issued in 1714 , the state was strictly forbidden to give the malikanes to people of reaya origin (Genç 2002, p. 107, note 16).

${ }^{12}$ During the time of the iltizam system there was a struggle going on among mütesellims to maintain their positions. Their opportunity to hold either mukataas or any source of revenue permanently was facilitated by the conversion of the lands into malikanes. See İnalc1k (1977, p. 33).

${ }^{13}$ In their articles, both Uzunçarş1l1 and Mert argue that the malikane system played a great role in the development of the ayanlık institution. Uzunçarş1l states that the malikane holders gained influence in the administration of the empire following this new land system (Uzunçarş1l1 1944, p. 41). As for Mert, he posits that by means of the malikane system, local notables not only started to take advantage of state revenues, but they were also given an opportunity to use state authority (Mert 1991, pp. 195-198). 
during the first half of the 18th century had already demonstrated that the best and most effective way of collecting taxes could be provided with the help of the local ayan. It was also well-proven with the introduction of the malikane system in the Ottoman Empire in the second half of the 18th century. There can be no doubt that the malikane system bolstered the emergence of provincial notables who then became eager for governmental positions in the 18th century. İnalc1k concludes: "the malikane system made a major contribution to the rise of a new landlord class with the rights, as free holders, over large tracts of state lands (miri), and it is in this practice that one has to look for the origins of the çiftlik system, and the rise of the village aghas (landlords) and the renowned 18th-century dynasties with large mukataa estates in their holding" (İnalc1k 1980, p. 329).

Taking everything into consideration, the malikane owners were equipped with huge financial and political privileges which not only threatened the central state's control over tax revenues and administrative sovereignty to reaya, but also opened the way for powerful ayan over time, especially in the countryside. Many other studies confirm this conclusion. For instance, Akdağ states that following the example of Egypt, where land ownership was granted for life, the Ottomans made local notables much stronger than before, and as a result, the local landlords turned into feudal lords (Akdağ 1970-1974, pp. 57-58). In a similar vein, Özkaya also asserts that this new system brought grist to the mill of the local notables who had already gained ground beginning around 1669-1670 (Özkaya 1977, p. 27). It even became, he argues, the raison d'être for the increased power of local notables in the Ottoman Empire (Özkaya 1977, pp. 109-110). Last but not least, Suceska posits that the malikane system not only increased the social and political power of the mültezims (tax-farmers), but also led to the emergence of wealthy ayan who soon became quite influential in the political life of the empire (Suceska 1985, p. 281). Examples of such empowerment for individuals can be clearly observed throughout the 18th century. Karaosmanzades, Çapanoğlus and Caniklizades are just a few examples. Detailed studies of each family reveal the fact that the malikane system played a role of prime importance in their economic, political and social development in the 18th-century Ottoman Empire. To give but one example, between the years 1737 and 1808 the Caniklizades held significant muhassillik of malikane in the Canik region where they were first firmly established as a family enterprise of high significance and then grew from a commercial enterprise into a military and administrative power controlling a large part of Canik region in northern Anatolia, especially between 1768 and 1792 (Şahin 2005, p. 33).

Although non-Muslim subjects of the empire were legally banned from acquiring malikane lands, they were not totally isolated and indirectly got involved in this new system as brokers, financiers or accountants etc. ${ }^{14}$ Namely, the necessity of paying the first installment in advance forced Muslim lessees to co-operate with moneylenders, most of whom were presumably non-Muslims. As a result, they had not only a great investment in the malikane system, but were also highly interested in what it

\footnotetext{
${ }^{14}$ This relationship between Muslim and non-Muslim subjects of the Ottoman Empire is called "Islamic business partnerships" (see Pamuk 2004, p. 241).
} 
brought to the Ottoman Empire. Even though such investments of the non-Muslims did not at first glance allow them to gain the status of Muslim ayan, they (at least financially) substantially benefited from the implementation of the system, which in the long run opened the way for them to have access to positions in the state apparatus, as we shall see shortly.

Essentially, following the wars of 1683-1699 the Ottoman Empire was forced to reconsider its functionality, and with a military debacle followed by fiscal shortfalls, the redistribution of wealth and position was its only option. The door was opened for the renegotiation and reorganisation of the empire in the face of changing socioeconomic and political conditions. Most malikane owners were either members of highranking state offices such as viziers, bureaucrats, and so forth, or members of the Ottoman dynasty, including female descendants. ${ }^{15}$ As Özvar states, by means of the $m a-$ likane system, high-ranking state officers found a great opportunity to transfer their temporal income coming out of the hass lands (land belonging to a member of the elite or to the sultan) into a permanent income (Özvar 2003, pp. 48-49). Namely, they had previously benefited from state lands during their period of office, which usually continued only for a very short period of time. However, when they purchased the hass lands as malikane, not only did they acquire a permanent source of income, but, as mentioned above, also complete freedom and immunity from state intervention for a lifetime. Frequent deposition of state officers and confiscation of their property at the hands of the empire, which had largely prevented the emergence of the aristocracy in the past, were simply not in effect within the malikane system. There is no doubt that this opened the way for the emergence of a social stratum - aristocracy - who had once been employed within the state apparatus, but did not necessarily remain faithful supporters after personally acquiring malikane land as their own "private enterprise".

By permitting local citizens to attend malikane auctions, the Ottomans spread economic and social benefits beyond members of the state class alone. A new class, composed of important figures from outside the capital, enjoyed the benefits of a new Ottoman system which basically turned them into members of the ruling strata with the bonus of being granted some official titles. Although some of these new interest groups became members of the ruling class, they were totally different from the ruling strata of the 16th century, whose rewards or punishments had been by and large at the hands of the sultan himself. These new members of the ruling strata were not much concerned about what the sultan expected them to do, nor did the sultan have the right or power to dispossess them of their lands, state positions or any other gained interests that this new era offered to them. After all, both the malikane system and the pasha households eliminated the right of the sultan to distribute the lands and state offices according to his will, as we have discussed above.

The Ottoman Empire overcame the issues that emerged with the war of 16831699 at the expense of changing traditional socioeconomic and political structures,

${ }^{15}$ Özvar's study clearly indicates that between the years 1695 and $1697,71 \%$ of the malikane holders were members of the military class and the rest were civilians. He also argues that pashas and their households were among the most important beneficiaries of the malikane system (Özvar 2003, pp. 60-68, 92-94). 
i.e., by depriving the sultan of his traditional rights and by renouncing his claim to be an absolute ruler in practice. This Ottoman flexibility and openness to necessary change resulted in an unsustainable recovery from the worst recession and revealed hopes for regaining all territories that had been lost following the sixteen-year war at the end of the 17th century. In a positive rebound, the Ottoman Empire succeeded in defeating Russia at Prut in 1711 and Venice in the Morea in 1715. Nevertheless, the Ottomans suffered another shattering defeat at the hands of Austria in 1717. But again, the Ottomans recovered and succeeded in scoring important military and diplomatic victories against both Austria and Russia in 1736 and 1739. In the meantime, the empire was also involved in a series of alternately disastrous and successful wars against Persia in the East. In the first half of the 18th century, the Ottoman Empire underwent some of the most disruptive economic, political, social and religious changes in its entire history. Nevertheless, it continued to be good at adapting to new eras and also largely succeeded in maintaining its integrity. After all, the empire was not only still successful to recruit soldiers, weapons as well as a good supply of ammunition for new military campaigns against its formidable enemies, but also continued to be seen as the most important centre of privileges and reward in the eyes of the Ottoman subjects through the malikane system. That is, obtaining the malikane was a bonanza for malikane holders and this is the very reason why the central government was still able to maintain some control in Ottoman provinces in spite of its lack of military power (Salzmann 1993, pp. 393-423).

\section{Longing for Past Glories of the Empire and Sultanic Authority in Vain (1699-1730)}

The Ottomans were thus saved from the threats of the first half of the 18th century, and retained economic and political integrity long after the Treaty of Karlowitz in 1699. This period between 1699 and 1730 constitutes the second stage of this paper where we shall try to answer the question of what happened following the Treaty of Karlowitz up until 1730. On the one hand, it began an era where both the redistribution of tax revenues and the decentralisation of Ottoman administration indicated a shift in power to those outside the palace. On the other hand, Ottoman sultans did not really give up their former claim of being absolute rulers and struggled to keep a tight rein on the newly emerged Muslim notables who had already begun to grow in the economic, political and social structure of the Ottoman Empire. After all, Ottoman statesmen believed that the worst had passed and the empire was once again on the right track (at least for a while). The first example of this feel-good factor can be observed in the 1710-1711 Ottoman-Russian War known as the Prut Campaign.

Following the famous battle of Poltava in 1709 (where Peter the Great's outnumbered army defeated Charles XII), the Swedish monarch took refuge in the court of Ahmed III. This incident, as well as Ottoman eagerness to regain its former influence north of the Black Sea, brought about Ottoman involvement in a new campaign to avert Russian expansions continuing both in Crimea and in Western Europe. In this 
new struggle, Peter's miscalculation and unpreparedness cost Russia dearly. The Russian strike force, composed of 32,000 infantry and 12,000 cavalry, attempted to prevent Ottoman soldiers from crossing the Danube in vain. In the meantime, shortage of supplies impaired the strength of the Russian army. The two armies met on the Prut River and their first encounter indicated the limits of Russian capabilities at that time. Conversely, however, we see the Ottoman Empire was pretty well prepared for the campaign. The Ottomans had sent orders to recruit soldiers from both Anatolia and Rumelia and were able to put more than 100,000 soldiers on the Prut River against the small Russian army. ${ }^{16}$ In the end, the war broke out and Peter barely saved himself from a catastrophe on the banks of the Prut River in July 1711. That is, only significant territorial, political and diplomatic concessions allowed Peter to turn back home safe and sound. Russia not only had to give up fortresses and fleets at Azov and Taganrog, but also the squadron based on the Prut itself, as well as other holdings on the Black Sea - all of which had been gained following the 1683-1699 wars and the Treaty of Istanbul in 1700. Again, Russia lost its former right of representation in the capital of the Ottoman Empire and gave the Swedish king safe passage back home. Lastly, Peter also promised to withdraw from Poland. Further arguments between the two states on the articles of this treaty were settled in the Treaty of Adrianople in 1713, which basically confirmed the agreement made on the Prut River. Most important of all, however, this was the very first time that Russia had tried to benefit from Orthodox subjects of the sultan. Peter had placed too much reliance on his intrigue and wrongly assumed that his army would be able to find all the supplies required in the liberated lands or from Christian subjects of the sultan longing for relief. The Ottoman Empire not only counteracted all Russian incitements, but also eliminated Moldavian and Wallachian rebels who had supported the Russian cause throughout the war.

The Prut campaign of 1711 testified to the strength and enduring success of the Ottoman Empire following the catastrophe of 1683-1699. More importantly, it wiped out the disgraces of the previous wars and allowed the Ottomans to reassert their self-confidence which had been shattered during the sixteen-year war. Russia was one of the most rapidly growing states in early Modern Europe and had scored great victories in many battlefields before and after the Prut River conflict. ${ }^{17}$ As a result, it is not surprising that the victory at the battle of Prut bolstered Ottoman confidence and Ahmed III, who had been hesitant in declaring war in 1711, did not falter in declaring another war against Russia on account of Peter's reluctance to comply with the requirements of the agreement. ${ }^{18}$ The Ottoman timidity of 1711 was soon replaced

${ }^{16}$ By one estimation, almost 130,000 Ottoman soldiers faced the Russian army of fewer than 45,000 (Dukes 1990, p. 72).

${ }^{17}$ To give an example, between the years 1700 and 1831 , Russia engaged in so many wars and lost only three of them, including the Prut battle in 1711, Austerlitz in 1805, and Friedland in 1807.

${ }^{18}$ Sultan Ahmed seems to be so confident in conducting another successful campaign that Findiklı Mehmed Agha argues that when he was informed about Peter's disobedience of the articles of the Prut treaty, he wrote a hatt-l şerif saying that if Russia continued to flout the articles of the treaty, he himself was going to make a campaign against the Russian infidels: Moskov keferesi üze- 
with the regret that Baltaci Mehmed Pasha could have easily scored a better victory against Russia and possibly even annihilated Peter's army once and for all. ${ }^{19}$

\section{The Phanariotes and the Emergence of Non-Muslim Elites in the Ottoman Empire}

Dimitri Candemir, who became a source of conflict between the Ottomans and Russia during that time, deserves a special mention here. Just one year before the war, Dimitri had been appointed as the ruler of Moldova by Ahmed III. Soon, however, the empire deposed him from this office when he promised to have food and supplies ready for Russian troops and later joined in the tsar's campaign at the expense of the Ottoman army during the battle of Prut. His aim was to use the Russians against the Ottomans in order to place Moldavia under Russian suzerainty. According to the treaty signed between Cantemir and Peter at Lusk in Poland on April 13, 1711, Moldovia was to be restored to its ancient formulation, and then accept the domination of Russia. Besides, Cantemir and his successors were to enjoy the sovereignty of the lands and no other family could be allowed to rule Moldavia until there remained no member of the Cantemir family (Dutu-Cernovodeanu 1973, p. 289). Despite being a failure, this agreement became important for two reasons. First of all, Cantemir's affiliation with Russia can be seen as the first moment when Russia was seen as liberator of the Christians from Ottoman yoke. ${ }^{20}$ More importantly, however, it opened the way for prominent Greek as well as Hellenised Romanian and Albanian families known as the Phanariotes ${ }^{21}$ to govern and dominate, first in Moldavia (1712), and then in

rine seferim var, bi z-zât kendüm giderim, ana göre müşâvere olunub din-ü devletime laylk ne ise rikâb-i hümâyunuma arz olunsun (Silahdar 1969, p. 277).

${ }^{19}$ One should not downplay the Russian defeat at the battle of Prut. After all, not long after 1711, Peter counterbalanced this defeat with the successful campaign of 1722-1723 against the Ottoman Persian vassals. For the time being, however, the Ottomans started to believe that all that had been lost during the disastrous wars of 1683-1699 could be recovered once again.

${ }^{20}$ Uzunçarş1l puts forward that Ahmed III was well aware of the Russian intrigue in Rumelia. He quotes a document sent to Hasan Pasha, the guardian of Selanik and Yusuf Pasha, governor of Özi. According to this note, the Ottomans warned them about some Russians who disguised themselves as merchants in order to provoke Christian reaya in the Balkans. Russian intrigue in the Ottoman territories bore fruit and the reaya of Montenegro rebelled against the Ottomans on the eve of the Prut campaign (Uzunçarşılı 1956, pp. 67, 70-72). Another striking document about Peter's attempt to romance the Orthodox subjects is provided by Hasan Kurdi. According to his story, Peter saw all Orthodox Christians as a single nation, and regarded himself as the ruler of this nation. He later urged Christians (Rum taifesi) to rebel against their Turkish overlords, which brought nothing in the end, however (Aksan 2007, p. 92).

${ }^{21}$ We are not sure exactly when the Phanariotes as a new institution emerged. Philliou mentions that its origin can be traced back as early as 1669, when Grand Vizier Fazıl Ahmed Köprülü remunerated Panagiotis Nikousios for his help throughout the siege of Crete. If we accept this as the beginning of the Phanariote era, we should also admit the fact that they rose to power roughly at the same time with the Muslim ayans. Even if we accept this as the beginning of the Phanariotes, this single example is far from resembling the elaborate power of the ayans at that time, which had been long established by then. Consequently, one should at least wait until the Treaty of Prut in 
Wallachia (1716), in the name of Ottoman sultans, thereby for the first time contributing to the emergence of non-Muslim state rulers within the empire.

Incidentally, in addition to the two voyvodes (local non-Muslim rulers) of the twin principalities of Moldavia and Wallachia, there were many other state positions that were already controlled by inhabitants of the Phanar district. That is, the dragoman of the court functioned as a middleman between European ambassadors and the imperial council as well as the Patriarch of Constantinople. The position of dragoman of the Ottoman navy was also granted to the Phanariotes and was second in importance after admiral of navy of the Ottoman Empire (kapudan paşa), and acted as de facto ruler of the Aegean islands as well as the coasts of Anatolia. There were many other crucial dragoman positions held by the Phanariotes, such as dragoman of Morea, who replaced former Muslim rulers after the reconquest of the region by the Ottomans in 1715 (Philliou 2009, p. 156). It is now clear that the Phanariotes had already been established in many Ottoman territories as a potent and powerful community by the first quarter of the 18 th century.

At first glance, the term Phanariote is often mistakenly used to identify Ottoman subjects of the empire who were not only Greek in origin, but also came from traditional Greek lands. As Philliou explicitly shows, however, using nationalistic and regional terms like Greek or Balkan in explaining the constituency of the Phanariotes is far from reflecting the complexity of group identity created among the Phanariotes. In spite of sharing some common features such as being Orthodox in religion, speaking Greek as lingua franca - and therefore being Hellenised - the Phanariotes came from a variety of backgrounds, significantly different from one another. In fact, their members consisted of distinct personalities including Romanian, Albanian, Tatar, Circassian, Serbian/Slavic, Vlach and even Armenian origins (Philliou 2009, pp. 170172). Consequently, it is not accurate to call them Greek notables of the empire. Their membership was open to any non-Muslim who could speak Greek and other foreign languages (especially French, which was quite widespread as a language of diplomacy at the time). By means of the position given to them after the Prut War, the Phanariotes not only gained further wealth from imperial grants, but also increased the political influence of non-Muslim aristocracies in the Ottoman Empire. ${ }^{22}$ In the course of time they also distinguished themselves as being the earliest channel through which European affairs became known to other non-Muslim subjects of the empire. ${ }^{23}$

In many respects, the Phanariotes resembled the pasha households of the Ottoman Empire. In practice, their future and fortune were at the hands of their masters rather than the sultan himself. According to Stoianovich, prominent Muslim figures

order to compare these two groups on any meaningful scale or terms. However, this does not deny striking similarities that helped them gain strength and climb the ladder in Ottoman administration (Philliou 2004, p. 176).

${ }^{22}$ Masters convincingly argues that members of the Phanariote families succeeded in dominating much of the wealth and commerce of the empire in the Balkans by the 18th century (Masters 2006, p. 279).

${ }^{23}$ Trypanis argues that with their stimulation of education for the Greek nation, the Phanariotes not only opened the way for a Greek War of independence, but also prepared other Balkan nations for a secession from their Turkish overlords (Trypanis 1963, p. 240). 
who were able to bequeath state positions to their heirs were mirrored by the Phanariotes, who also started to enjoy state titles such as bey or prince, indicating their elevated status in Ottoman administration (Stoianovich 1963, p. 302). Sadat also argues the same by pointing out that just like the ayan and aşraf (notables of a town or village) of the empire, the Phanariotes, in co-operation with local leaders of Moldavia and Wallachia, took the benefit of converting lands into hereditary properties (Sadat 1972, p. 350). This trend becomes more believable when we learn that from 1711 until 1770 , there were only three Phanariote families that were considered for the position of voyvode in Moldavia and Wallachia (Sözen 2000, p. 187). It is particularly remarkable that the monopoly of these three families did not end until the last quarter of the 18th century, when we start to see more and more Phanariote families becoming involved in the administration of these two provinces for the first time.

The Phanariotes, one way or another, opened a channel through which nonMuslim elites of the empire acquired a right to rule two provinces of the empire on behalf of the sultan. Unsurprisingly, over time this led to further influence of other non-Muslims in the empire too, as we will see below. Suffice it to say that throughout the 18th century, crucial state positions in the Ottoman bureaucracy - including grand dragoman, undersecretary of grand viziers, dragoman of the imperial navy and undersecretary of the fleet - were monopolised by prosperous non-Muslim elites. Such important ranks, as well as that of the voyvodes or governors of Moldavia, Wallachia and Morea etc., gradually created very powerful non-Muslim elites who occasionally shared common interests with and contributed to the expansion of the Greek merchant class (Leon 1972, p. 26).

However, one should not exaggerate the power of the Phanariotes at this stage and describe it as being totally equal in importance to pasha households in the empire. After all, their patrons had to be on friendly terms with dominant figures of Istanbul in order to protect their positions either in the twin principalities or anywhere else in the empire. Unlike the pasha and their households who held the highest state offices in the capital more permanently, ${ }^{24}$ the will of the sultan (or even that of a high dignitary such as a grand vizier) would have been grounds for deposing a Phanariote or replacing one with another. Furthermore, unlike the ayan, the Phanariotes were neither military commanders nor allowed to acquire iltizam or malikane under any circumstance. As non-Muslim subjects of the empire they were also occasionally subjected to second-class status in the Ottoman Empire despite the fact that they were still able to accumulate certain lands and unique privileges as governors of Wallachia and Molda-

${ }^{24}$ A striking example to show how these new Muslim elites were successful in keeping their positions is that a member of Ottoman high aristocracy was always involved in the question(s) of deposing Ottoman Sultan(s) in the 17th and the beginning of the 18th centuries. Abdülrahim (chief jurist consul of the empire at the time) approved the position of Ibrahim I in 1648. About forty years later in 1687, Abdülrahim's son Mehmed (the chief justice of the Asian and African provinces) acknowledged the regicide of Mehmed IV (son of Sultan Ibrahim). Last but not least, Yahya (son of Mehmed the Judge) attained the position of the chief justice of the Asian and African provinces in the Ottoman Empire following the deposition of Mustafa II (son of Sultan Mehmed) in 1703. To make a long story short, "Mustafa II came to be deposed, among others, by a jurist whose father had deposed his father and whose grandfather had deposed and executed his own grandfather" (Tezcan 2010, p. 6). 
via. Philliou still concludes that in spite of their difference in acquiring political and economic power, both the ayan and Phanariotes took important roles in the Ottoman governance in the late 17th and early 18th centuries. In the end, they created their own authority through their military, diplomatic and political skills desperately needed by the central government at that time (Philliou 2009, pp. 176-178).

One should also take into consideration the relationship between the Phanariotes and the Orthodox Church in Istanbul. The Church had the right to sanction the voyvode who had been appointed by the imperial council. There was even a special religious ceremony enacted each time a new voyvode was sent to Moldavia and Wallachia. This does not mean, however, that the Patriarch had something to do with the appointment of a candidate or had the right to give him civil authority. It was the duty of the imperial council in general and grand viziers in particular to nominate certain candidates and decide who was to be a voyvode of the twin principalities. At this juncture, the Patriarch of Constantinople had no choice but to reiterate the appointment and bless the new initiate on behalf of God (Philliou 2004, pp. 38-39). Dominance of the Ottoman Sultan over the voyvode became solidified after their nomination by grand vizier(s) and blessing by the Patriarch were completed. That is, investiture of a Phanariote was only legitimate after the main ceremony held before the Ottoman Sultan. As a rule, this ceremony of investiture was to start on a Tuesday not only as a reminder of the Ottoman conquest over the Orthodox, but also as a demonstration of the symbolic entrance of the voyvode into the sultan's chamber. The voyvodes were also accepted to military rank in the Ottoman Empire by enjoying the special soup prepared and shared by the Janissaries during this ceremony (Philliou 2004, pp. 4446). All together, they symbolise the sultan's secular hegemony over Christians in general and Phanariotes in particular. In a similar vein to the previous century, therefore, they might have been more likely to see the Sultan as the source of reward or punishment (at least at this stage), in opposition to the Muslim pasha households that held a more elevated status and did not suffer Sultanic interference in the same way as non-Muslim elites did.

\section{New Ottoman Self-Confidence and Attempts to Strengthen Sultanic Authority}

Starting with the Treaty of Karlowitz, the Ottoman Empire refrained from engaging in another battle in Europe until the battle at Prut. Despite being hesitant at the outset at the battle by the Prut in 1711, the Ottomans proved their strength and ability to recover some of the lands they had lost during the devastating wars of 1683-1699. Following the Prut victory, the next adventure that the Ottomans undertook would be completed with greater ease. At this time, it was well known to any Ottoman statesman that Venice had lost the strength of its glorious past and therefore was far from matching the Ottoman Empire. Besides, scholars assert that Venetian officials and priests were proving predictably unpopular with the Greeks who preferred the rule of 
the Ottomans to that of the Venetians. ${ }^{25}$ Last but not least, the Ottomans were now self-confident enough to confront Venice in another campaign. After all, the last notable Ottoman victory just before the wars of 1683-1699 was also scored against Venice with the conquest of Crete in 1669, after a 21-year siege. Further, many thought that the empire had lost control of the Morea only because it had been forced to confront all states of the Holy League at the same time. Therefore, the victory of the empire against Russia in 1711 cannot be seen as the only reason for Ottoman confidence at the outset of the Ottoman-Venetian War of 1715, but rather it served to trigger another campaign at the expense of Venice whose weakness was too alluring to be ignored by Ottoman statesmen looking for the restoration of the lucrative lands previously lost to this opponent.

Two reasons had been given for the declaration of war in December 1714 . Venetian support of Montenegrin rebels was one of them. Accordingly, the Ottomans blamed Venice for urging the people of Montenegro (Karadağ) to take up arms against the Ottomans and even accused Venice of protecting those insurgents who had rebelled to overthrow the Ottoman government in Montenegro. The second cause for Ottoman aggression was the Venetian breach of the terms of the Treaty of Karlowitz. Namely, Venetians were not allowed to take part in any pirating activities against Ottoman vessels in the Mediterranean Sea. ${ }^{26}$ Yet, it was argued that Venice did not refrain from attacking them and committing piracy or armed robbery against Ottoman ships. As a matter of fact, although the issue had cropped up immediately after the Treaty of Karlowitz, the Ottoman Empire was so afraid of inflaming hostility in the first decade of the 18 th century ${ }^{27}$ that instead of directly suppressing the rebellion in Montenegro at the outset, the Ottomans followed a policy of reintegrating the rebels into the Ottoman system without provoking any of the European states of the 16831699 wars. The empire followed this policy until 1713, when the Treaty of Adrianople was signed and there was no further need to fear a Russian attack. ${ }^{28}$ Only after that

${ }^{25}$ The transition from Venetian to Ottoman rule in the Morea was most welcome by the Orthodox people who thought the Ottoman system to be more tolerant than the rule of Catholic Venice. As a matter of the fact, there was a surprising degree of similarity between Venetian and Ottoman rule, which made the transition either from Ottoman to Venetian rule, or vice versa, quite easy. The Orthodox population's preference of the Ottomans therefore derived not from a distinct system between Venice and the Ottoman Empire, but rather from the difference in religious tolerance. See Motraye (1723, vol. 1, pp. 333-334); Brue (1870, pp. 14-19); Davies (2007).

${ }^{26}$ According to this treaty, piracy or engaging in any illegal activities in the Mediterranean was to be avoided. The first article says that there would be no attack either from the Morea to Ottoman coasts in Aegean Sea or from Ottoman lands to the Morea. Article 19 also prescribes that Venetians are not allowed by any means to protect pirate vessels (see Ertaş 2007, p. 21, note 25).

${ }^{27}$ When the governor of Bosnia, Numan Pasha, was sent to suppress the rebellion, the rebels ran away to some Venetian-ruled islands. Numan Pasha did not dare to follow them so that he would not violate the articles of the Treaty of Karlowitz (Mehmed Raşid 1865). To observe the close relations between the Venetians and the rebels, see Silahdar Findiklı Mehmet (1969, pp. 22-23).

${ }^{28}$ It does not necessarily mean that the Ottomans were certain that Russia would not take part in favour of Venice. In other words, during the campaigns the orders sent to the leaders of the Crimean Khanate proved that the empire did its best not to provoke Russia and warned the Tatars 
did the Ottomans take this rebellion seriously and delivered an ultimatum to Venice: "do not protect or support the rebels against the Ottoman Empire in any way".

Nonetheless, the empire did not have a completely free hand to face the Venetians. In spite of being well aware of Austrian disarray due to the Spanish succession quarrels in Europe, the Ottoman Empire had no desire to have another war with Austria which had been the guarantor state of the Treaty of Karlowitz. ${ }^{29}$ Consequently, Ibrahim Müteferrika was sent as ambassador to Vienna to justify the forthcoming Ottoman attack on Venice and to fulfill Ahmed III's wish to keep the Austrian monarch out of this war. Ibrahim argued that the Ottomans respected the Treaty of Karlowitz, but they had to put an end to Venetian greed both in the Morea and the Mediterranean, which could only be interpreted as an open violation of the treaty of 1699 (Roider 1982, p. 41). In addition to Austria, the empire felt compelled to justify its actions in the presence of the embassies of England and Holland. Accordingly, the Ottoman statesmen officially explained the reasons why they had no choice but to attack the Venetians in the Morea (Ertaş 2007, p. 24, note 35). It is now clear that since 1699, the Ottomans had been trying to avoid facing two enemies at the same time, and did their best not to commit the same mistake as in the wars of $1683-1699 .{ }^{30}$ Especially after the Prut war, therefore, the empire was well aware of its strengths and limitations, and endeavoured to take advantage of the diplomacy which had already started to gain the upper hand for Ottoman decision-making towards the end of the 17th century.

Ottoman policy bore fruit, and Venice had to stand alone against the Ottoman attack which began in the spring of 1715 . As had been rightly predicted by the Ottomans, Venice was too weak and insufficiently prepared for the assault. Soon, the Ottoman naval and military operation against Venice brought the republic to its knees, and in just a few months (to be exact, 101 days), the Ottoman Empire was not only able to reconquer the Morea, but also put an end to the Venetian control of some of the islands that had never been under Ottoman domination before. ${ }^{31}$ There is no doubt, on the one hand, that despite the difficulties the imperial army had experienced during

to obey the articles of the Treaty of Karlowitz so that Russia would have no reason or excuse to attack Ottoman territories. See Ertaş (2007, p. 24).

${ }^{29}$ Silahdar mentions that the empire was very worried about possible Austrian participation in the war due to the fact that the Habsburgs might have thought that they were to be the next target of the Ottoman Empire after Venice (Silahdar Findıklı Mehmet 1969, pp. 37, 330).

${ }^{30}$ Kurat argues that long before the Ottoman expedition in the Morea in 1715, the Ottomans were afraid of Austrian participation in a struggle that would end in favour of the former member of the Holy League. Accordingly, even before the Ottoman expedition of 1711 against Russia, the Ottomans did their best to prevent the Habsburgs from taking the Russian side. For that purpose, the empire not only sent an embassy to Austria, but also tried to persuade Talmann, the Austrian ambassador at the time, that they desired nothing but friendly relations with their neighbour (Kurat 1951, pp. 198-200).

${ }^{31}$ During the Morea expedition the Ottoman Empire was also able to capture some of the islands that had been ruled by Venice for a long time. Egine and Çerigo can be given as examples for those islands. Likewise, some other fortresses in Crete which could not be taken earlier were also brought under Ottoman domination. Suda and İsperlonga were just two of them (Ertaş 2007, pp. 27-28). Canım Hoca Hacı Mehmed Pasha also conquered Tinos (İstendil) and Cerigo/Çuka islands (Kiel 2007, p. 38). 
the Morean expedition, this immediate capture of the Morea increased Ottoman selfconfidence, which had been restored to certain degrees after the War of Prut. On the other hand, however, it triggered Austrian suspicion and distrust that they would be the next target of the Ottomans. ${ }^{32}$

Before going any further, one should look at the important changes that the empire had to make following the Treaty of Karlowitz. It was only by making these alterations that the empire was victorious both at Prut and in the Morean expedition. Accordingly, local ayan not only started to play an important role in the imperial army, but consequently they also enjoyed the benefits that the new system brought about. These changes are illustrated in the writings of Mehmed Raşid and Küçük Çelebizade Asım. To give just one example, Raşid talks about an ayan called Müminzade Abdülmümin Efendi, and his increasing influence in Yenişehir. Müminzade not only made his fortune, but his enormous wealth allowed for his acquisition of one of the ulema's (i.e. learned religious class) titles (Bosna pâyesi). He later abused the privileges this title brought for his own personal gain. Again, he used his fortune to bribe high-ranking Ottoman officers for their protection, and hired vagrants to bother kadls (judge) who had no desire to affiliate with him. As a result, the reaya of Yenişehir sent a letter of complaint to the commander of the imperial army, i.e. the Grand Vizier Damat Ali Pasha who led the Ottoman army to crushing victory in Morea in 1715. In response, the ulema title was taken from Müminzade and was replaced with a military title (Bosna pâyesi alâiye beyliği), and he was sent to the Morea expedition with a thousand soldiers (Mehmed Raşid 1965, pp. 60-61; see also, Küçük Çelebizade Asım 1865, pp. 441-442).

This is very important to our understanding of the change that occurred in Ottoman mentality following the long wars of 1683-1699. Namely, the Ottomans opened the way for local notables to obtain financial benefits and also utilised that wealth for further gains within the empire. One can safely argue that this trend came into being after the Treaty of Karlowitz and already started to bear fruit by 1715 . On the other side, the Ottomans intended to use their increasing power and influence over the ayan for the benefit of the state, in particular during times of war. The example mentioned above is also significant in showing that the Ottomans not only called up the ayan as a military power in the Morea, but also (possibly in return) gave them distinguished official titles as was the case of Müminzade Abdülmümin Efendi. In conclusion, by the first quarter of the 18th century, in the eyes of Ottoman statesmen, the military and economic power of the ayan was so significant that the empire could not help taking advantage of their presence in Ottoman campaigns.

${ }^{32}$ Silahdar quotes Ahmed III's statement that "there was no need to worry about the enemy. In just thirty days I was able to reconquer the Morea which had been conquered thirty years before by my ancestors". And he decided to make a further campaign against the Venetians. (ahâl-i düşmen hiç de hiç imiş, işte varub gördüm, ecdadın otuz senede mâlik olduğu mülke otuz günde muvaffak kıldım, hayf geçen vüzerâya, işleri ihânet imiş, ancak cümle mülûk-i nasarâ hareket ider ise de din-i Muhammed Ali cümlesine inşa'Allah cevab virülür, taraf taraf yani ki, berr-ü bahrden Venedik keferesi üzerine sefer idelüm. In: Silahdar Fındıklı Mehmet 1969, pp. 336-337.) 
Aside from Ottoman chroniclers, we have many other authors discussing the increasing influence of the ayan throughout the 18th century. In his book, Cezar scrutinises some of these examples and comes to the conclusion that starting from the first quarter of the 18th century, the ayanlik, the institution of provincial notables in the empire took root and the Ottoman state began to give it more and more responsibilities and duties, including recruiting and transporting troops to military fields, protecting the countryside against banditry, and many other military duties of high importance. Unsurprisingly, the ayan did not refrain from abusing this newly endowed authority for their own benefit. ${ }^{33}$

Ottoman self-confidence supported by the help of the ayan even led Damad Ali Pasha to send another fleet to capture Venetian headquarters on the island of Corfu in 1716 (Uzunçarş111 1944, p. 109). At this time, however, Ottoman fortune turned for the worse: the Habsburgs declared war on the Ottomans under the pretext of Ottoman violation of the Treaty of Karlowitz. Soon, everything turned upside down, and once again things went out of control in the Ottoman Empire. In fact, by sending a letter, Ali Pasha had endeavoured to receive Austrian approval for the Morean expedition, or at least tried to persuade Austria that the Ottomans had no intention of breaking the articles of the Treaty of Karlowitz. Rather, he wished to preserve the peace before launching the campaign. Yet, Austria did not respond positively and tried to buy some time in order to detain the Ottomans from immediately taking any further action against Venice. In response, Ali Pasha replied that it was not reasonable to keep so many imperial soldiers under arms for an indeterminate period of time, and decided to attack the Morea without waiting for any official approval from Austria. But he did not burn all bridges with Austria, of course, and left a door open for future negotiation with the emperor (Mehmed Raşid 1965, pp. 197-198). Indeed, Ali Pasha hoped that Austria would not take part in another campaign after having been defeated by France and signing the Treaty of Rastatt following the Spanish wars of succession in 1714. After all, this had been the Austrian attitude toward the Ottoman-Russian Wars of 1711. Thus, early Austrian hesitancy let the Ottoman Empire mistakenly believe that the Habsburgs were going to reiterate this same policy of neutrality in 1714 as well.

The Ottomans were forced to wake up from careless confidence and were thrown into a complete state of confusion. Instantaneous victories of the imperial army against Russia and Venice had already worried the Habsburgs who now found it pointless to believe that the Ottomans would stop pursuing their policy of revenge. Rather quickly, Austria decided to declare another war on the pretext of restoring the status quo ante in favour of Venice. Consequently, it struck another devastating defeat over the Ottoman imperial army at Varadin in August 1716 which opened the way for the loss of both Banat and the fortress of Belgrade in 1717. The Treaty of Passarowitz, signed after the capture of Belgrade in 1718, sealed not only the dramatic alteration in the balance between the Ottoman and Habsburg Empires, but also represented a new century for the Ottomans, as we will shortly see in greater detail. Suffice it to

${ }^{33}$ Cezar also argues that the ayan power reached its apogee during the Ottoman-Russian Wars of 1768-1774 when they were given all responsibility for the creation of the Ottoman army (Cezar 1965, pp. 337-338). 
say that on the eve of the second siege of Vienna, the border between the Ottomans and Habsburgs was not in favour of the latter, i.e. just a few days' march from the capital of the Habsburg Empire. After the Treaty of Passarowitz, however, the Danube and Sava Rivers now became borders between the two long-standing enemies, which of course reversed the military balance in favour of Austria. From this point on, it was not the Ottomans but rather the Habsburgs who had penetrated deep into the Balkans, and presented a very real threat to the existence of the Ottoman hegemony there. In brief, it was a well-known fact to both the enemies and the friends of the Ottoman Empire that it was no longer a military danger to its formidable adversary in the West (Wheatcroft 2009, p. 234).

Nevertheless, even if Austria's power reached its apex at the expense of the Ottomans with the Treaty of Passarowitz, the Ottoman Empire continued to attempt to prove its strength and launched successful campaigns against Austria in the following decades, as well. That is, the Ottoman-Austrian Wars of 1737-1739 and 1788-1791 indicated that the Ottomans succeeded in firmly holding ground, repelling their opponents and even occasionally gaining some lands long after 1718 . However, the military humiliation of the Ottomans - a product of the Treaty of Passarowitz - dealt a deadly blow to the insoluble self-confidence of Ottoman high dignitaries in the West. This pact brought into the sharp relief that, for the Ottomans, there could be no going back to the glorious ages of the 16th and 17th centuries, when the empire had been merely stating terms for its big enemies rather than hoping for mediation or conciliation to stop any devastating war. The Treaties of Karlowitz and Passarowitz marked the end of European fear of the "Turkish menace" in Europe. Moreover, the Ottomans started not only to accept the superiority of its Western opponents, but also to explicitly imitate the military formation and equipment of the West, as well as a Western culture and way of life. This last point can be seen as a tremendous blow to the longstanding principle of Muslim superiority over Christian infidels. Last but not least, the necessity of building a network with European states after the Treaty of Passarowitz not only created a prosperous non-Muslim class, but also resulted in a gradual growth of its power and influence in the government.

On balance, from the Treaty of Karlowitz up to the treaty of Passarowitz the Ottoman Empire apparently recovered from the catastrophe of 1683-1699 and began to look at the future with hope and confidence rather than fear and anxiety. Soon, however, the Ottoman-Austrian War of 1717 and the Treaty of Passarowitz thereafter illuminated the fact that the time interval between these two treaties had not actually helped the empire to regain the spirit of the 16th and 17th centuries. The illusion of successes at the Prut against Russia, or in the Morea against Venice, did not result from Ottoman adaptation to a new system of military conflict, but rather from taking the advantage of local ayan by giving them certain incentives for the encouragement of individual valour, which partly annihilated the technical difficulties of moving Ottoman troops and supplies that the empire had faced in the long wars of 1683-1699. With only such slight rearrangements in the imperial army, they could only save the day at best. As we understand from some writings of the contemporary sources, the impetuous fighting style and unruliness of the imperial army were still in practice, and 
Turkish discipline and drills were constantly poor even during the successful expeditions of Prut and the Morea. ${ }^{34}$ These continued to be the most vulnerable points of the Ottoman Empire throughout the whole 18th century.

One thing needs to be kept in mind though. Both victories at the Prut and the Morea led Ahmed III (1703-1730) to attempt to revive the sultanic authority in the empire, which had reached its lowest ebb following the deposition of Mustafa II in 1703. After all, both successes gave Sultan Ahmed good reason to reclaim the power of his successful predecessors. The first sign of this inclination can be observed immediately after the reconquest of the Morea in 1715. The Sultan ordered reimplementation of the timar (land grant, fief) system in the Peloponnese instead of the malikane system, which took root in the Ottoman territories immediately after it began. After all, the malikane system was a catalyst for the emergence of the Muslim notables after 1695 as we have seen before. Therefore, his preference in favour of the ttmar system, where none but the Ottoman sultan was seen as the source of reward or punishment, might be easily interpreted as Ahmed III's first attempt to revive the former prestige and power of the Ottoman sultans. Not long afterwards, the Sultan decided to abolish all malikane lands once and for all on account of having realised a huge tax loss in the imperial treasury about twenty years after its first implementation. Apart from seeing this as an attempt to increase the taxes, which was more or less forbidden in the malikane system (Genç 2002, p. 113), one can see this change as an attempt to take back the possession of economic sources from the hands of the Muslim notables as well. In the end, however, as mentioned above, the empire suffered devastating defeats at the hands of Austria between the years 1716 and 1718. Consequently, not only was the implementation of the tımar system abolished in the Morea, but also the state declared the reimplementation of the malikane system all over its territories by reselling its lands with slightly better value in 1717 .

This was not the end of Sultan Ahmed's attempts to retake control of the Ottoman Empire at the expense of the newly emerged notables of the time, however. Quataert argues that there was an important similarity between the court of Louis XIV

${ }^{34}$ Yildiz's studies on the Ottoman imperial edicts and documents proved that there is a substantial number of official documents in the Ottoman archives which were sent to threaten or warn undisciplined soldiers of the Prut campaign (Y1ldiz 2006, pp. 129-131). A contemporary eyewitness, Sir Robert Sutton, wrote on April 6, 1711 that "The Vizier decamped with the Forces assembled at Daud Pashaw the 26 past, pursuant to a Hattescheriffe or Order under the Grand Signore's hand. This sudden departure, which happened 15 or 20 days sooner than the Vizier expected, was chiefly occasioned by the Sultan's uneasiness at the great disorders, insolences and quarrels of the Soldiers, which were indeed extraordinary, they being under no obedience, discipline or Order, and neither Government nor their own Officers daring to punish them, insomuch that there was no other remedy found but dispatch them away" (Sutton 1953, p. 45). Benjamin Brue's book is full of examples indicating how the Janissaries got out of control during the whole Morea expedition. To give but one example, even though they were not allowed to plunder one of the places in the Morea as a result of the agreement made between Reis Efendi and the Venetians, they were eager to loot there and attacked the Venetians. In the meantime, some of the gun powder had caught fire and caused the deaths of many people. Ottoman officers were simply not able to stop them from putting Venetian soldiers and officers on the sword and killing all inhabitants - Greek men, women and children (Brue 1870, pp. 17-19). 
at Versailles and that of Sultan Ahmed III during the Tulip Era, a time of extravagance, conspicuous consumption, and cultural borrowing from the West. During this time, the Sultan and Ibrahim Pasha intended to keep tight reins on members of the pasha households as Louis XIV of France had targeted his elite citizens about fifty years earlier. That is to say, by creating some costly commodities such as tulip breeding, luxury goods, pleasure palace building and festivities, etc., the Sultan and his son-inlaw sought to eliminate or at least pacify the pasha households or the Ottoman elites who had became quite influential in administrative decision-making by that time. Particularly important is here that their main target was none but the malikane holders who had already gained enormous political and economic power by that time (Quataert 2005, pp. 43-44, 148). ${ }^{35}$

In a similar vein, Finkel argues that Ahmed III used his daughters in order to consolidate his authority by assuring the loyalty of Ottoman statesmen to the dynasty by offering his daughters to them in order to establish affinity by marriage. Accordingly, Ahmed had thirty daughters, many of whom married (even more than once, after being once widowed of course) high-ranking state officers. It was the Sultan's intention to create a new stratum that might become much more eager to serve the Ottoman dynasty with utter faithfulness and obedience because they had access to the rewards of association with the royal dynasty (Finkel 2006, pp. 338-339). We do not exactly know what the Sultan and his Grand Vizier really aimed at achieving during the Tulip Era, but what we know for sure is that if they had desired to keep control over the newly emerged class, they were not that successful and fell far short of attaining their objectives in the end.

\section{Ottoman Westernisation and New Attempts to Regain Ottoman Prestige in the East}

The Peace Treaty of Passarowitz in 1718 forced the Ottomans to rethink their position. At first glance, Ottoman belligerency was willingly or unwillingly replaced with peaceful relations with the West. After all, the defeats of the Ottomans, which attested to the military, organisational and technological supremacy of European armies, convinced the Ottomans that the danger of new military adventure in the West was too big to be pursued. In addition, just like the devastating impacts of the 1683-1699 wars upon the Ottoman economy, the wars of Venice in 1715 and especially that of Austria in 1718 once again forced the Ottomans to solve its urgent need for money to restore the empire after Passarowitz. As a result, one of the most burdensome taxes called imdad-l seferiye that had rarely been collected before started to be assessed annually after 1718, and increased the agitation among the population (Barkey 2008, p. 203).

${ }^{35}$ In a sense, having looked at the Ottoman elites of the Tulip Era who were interested in festivities, luxury, expensive habits and pleasure seeking, Barkey also agrees with Quataert by saying "The Sadabad was the Versailles of Istanbul" (Barkey 2008, p. 214). In a similar vein, Eldem also sees striking similarities (as well as differences) between the Ottoman Empire and France during the 17th and 18th centuries (Eldem 1998, pp. 14-32). 
That is to say, before 1718 imdad-l seferiye had only been collected during war-time, but now, with the name of imdad-l hazariyye, it was imposed during peace-time as well. Most important of all, the collection of the imdadiye was given to local leaders called mutasarrifs, thus both enriching Muslim notables and increasing their influence in the Ottoman Empire once more. ${ }^{36}$

In the meantime, the Ottomans also gave up sending governors of slave origins to provinces and towns in 1726. Instead, leading figures of each vilayet (province) or sancak (district) were supposed to choose their governors among local notables. Kaymaz calls it nothing less than the transition of the Ottoman regime to the ayan regime since it fundamentally changed Ottoman government, society, economy, culture, and even policy in favour of the ayan. It means that the monopoly of the kapukulus (Janissary) and ulema of Istanbul who had been at the centre of all important decisionmaking in the empire before now started to lose their power with the emergence of ayan in the provinces. From this point on, the power of the ayan needed to be taken into consideration in almost all state affairs of the empire (Kaymaz 2002, pp. 145146). ${ }^{37}$ To be precise, between 1683 and 1730 the Ottomans enjoyed less than twenty years of peace, and the Ottoman economy was less and less able to afford wars. It was only through the new elites, i.e. the ayan that the Ottomans were able to raise the required money. Whereby, whether deliberate or not, the ayan started to get the upper hand in this new socioeconomic system of the empire as discussed above.

Following the Treaty of Passarowitz, which marked the beginning of the Tulip Era, Ottoman dignitaries looked at the European states differently than in previous centuries, and started to appreciate at least some of the developments that had already taken place in the Western states. European culture as well as technology came into value and began to be imitated in Ottoman agenda as well. For instance, almost three hundred years after the invention of the printing press by Johannes Gutenberg in the West, the first printed text in Ottoman Turkish was published in 1727 by a Hungarian convert called Ibrahim Müteferrika (1674-1745). In a similar vein, light artillery and a new corps of firemen in the European style were also introduced by Comte de Bonneval (1675-1747) who was known as Humbarac1 Ahmed Pasha after he had converted to Islam. It was also a time when Western tastes had great influence on Turkish culture, including architecture, music and so forth.

${ }^{36}$ Raşid states how this extraordinary tax became a great burden to the reaya after 1718 and notes the state's attempt to eradicate abuses made in the process of the collection of imdad-l seferiye. During that time, it became a source of income given to the mutasarrifs of eyalet and sancak (Mehmed Raşid 1865, pp. 384-385). This arrangement in tax increased state revenues, as we understand from the contemporary writings. For example, by looking at the report of Chief Defterdar ElHaj Ibrahim Efendi, Belin states that the total income of the empire increased to 1,140,027 gurus from 1718 to 1721 (Belin 1864, p. 213). See also Türkiye Diyanet Vakfi Islâm Ansiklopedisi (Istanbul, Divantaş, 2000), s.v. "İmdâdiyye".

${ }^{37}$ Akdag also states that this change in the appointment of the governors through eliminating people of slave origin might have caused the emergence of the ayan in some areas, who soon became strong enough to resist the Ottoman authority in the lands under their control (Akdağ 19701974, p. 51. 
This was the advent of a huge change in the Ottoman attitude toward the West. This alteration can first be observed in Ottoman documents sent to France and Austria. Unlike in the previous centuries, in imperial edicts we begin to see expressions like "Our grand/supreme/majestic friend" before the names of Western rulers (Uzunçarşıll 1956, pp. $170-171){ }^{38}$ More and more Ottoman envoys started to be sent to European capitals, but unlike in previous centuries, their task was not simply giving or receiving letters or attending coronations, they were now also required to observe the European states so that they might impersonate their style and technique in conducting international relations such as negotiating alliances, treaties and agreements. To give but one example, Yirmisekiz Çelebi Mehmed Efendi was sent to Paris between the years 1720 and 1721 in order to observe the features of Western civilisation and education which might be beneficial if they were applied in the Ottoman Empire. The earlier Ottoman sense that their superiority was indisputable was replaced with the desire to understand and even to follow Western civilisation (Yirmisekiz Çelebi Mehmed 1993). It is safe to argue that the Treaty of Passarowitz caused some Ottoman officers to imitate their "infidel" foes who could neither be ignored nor looked upon with contempt any more. ${ }^{39}$ Indeed, it is not reasonable to think that there had been no contact between the Ottomans and the West before the 18th century. Yet it is only after Passarowitz that the Ottomans acknowledged defeat and realised the superiority of the Western system, which became the stimulus for the emergence of a new Ottoman approach to the West (Berkes 1964, p. 24). McGowan argues that "after a second round of punishment, ending with the Treaty of Passarowitz (1718) we see the first evidence, at the very top of society, of experimentation with Western models" (McGowan 1994, p. 640).

There is no doubt that Ibrahim Pasha was firmly resolved to keep the peace and have good relations with the European states long before the Treaty of Passarowitz was signed in 1718 (Ahmet Cevdet 1858-1883, pp. 148-152). Unsurprisingly, during his period of office (1718-1730) this became an unchanging Ottoman foreign policy of the empire to the detriment of Ottoman boast. Nevertheless, this does not necessarily mean that the empire completely gave up its belligerent posture toward all its neighbouring states. That is, Ottoman determination to gain further lands at the expense of other states continued after 1718. But from this date onwards the target was no longer

${ }^{38}$ A short time later, a similar change to Ottoman references to the heads of foreign states can be observed in Persia as well. According to Belin's account, following the treaty signed between the Ottomans and Persians in 1742, the former agreed to using the title châh and qâân to refer to Nadir Shah of Persia, which had not been the case before (Belin 1864, p. 228).

${ }^{39}$ Berkes's study gives an important example of changing Ottoman attitudes of the time. Accordingly, İbrahim Müteferrika, founder of the first Turkish printing press in Istanbul, wrote a book under the title 'Usûl ul-Hikem fi Nizâm ul-Ümem, where he looked for an answer to the question 'what went wrong in the Ottoman Empire?' in opposition to Christian nations that had defeated the empire. This book is particularly important on account of having been written immediately after the Patrona Rebellion in 1731, when the reaction to everything coming from the West was so widespread. But nothing prevented Ottoman statesmen like Müteferrika from admitting the fact that the Ottomans had lagged far behind the West, and maybe more importantly, his only solution was to scrutinise Western culture in the same way as Russians had done successfully before and imitate its new methods in defending and protecting their lands. As a result, 'ignorance of the new methods of the Europeans' was given as the main cause of Ottoman failures (Berkes 1964, pp. 42-45). 
the West, which no longer proved to be an easy prey for the Ottomans, but the East, which not only shared common difficulties with the Ottomans at that time, but had recently begun to suffer from the Persian wars of succession.

The Ottoman Empire was at peace with Iran for almost a century following the Treaty of Zuhab in 1639, in spite of ongoing sectarian clashes and conflicts that had sparked many wars throughout their history before. However, the extreme weakness of Iran following the death of Hüseyin II tempted not only the Ottomans but also the Russians to attack Persian provinces in the north. Afterwards, in return for recognising Peter the Great's conquest in the Caspian, Russia gave consent to the Ottoman annexation of the provinces Azerbaijan, Kermanshah and Luristan. It is noteworthy to throw into sharp relief here that the Ottomans were obsessed with the new diplomacy when searching for alliance, negotiation and co-operation with possible comrades, replacing the former one-sided Ottoman dominance of earlier centuries. ${ }^{40}$

At the outset, the Ottoman Empire was victorious in the lands of what had been their chief Muslim rival, the Shi'i Safavid shah of Iran. Lewis posits that the Ottoman imperial army was as efficient as before, but it was European innovation in the military field that indeed changed the balance of power against the Ottomans (Lewis 2002 , p. 20). If we accept his argument, it is no wonder that the Ottoman scored a great victory in the East, since both the Ottomans and the Persians more or less kept their traditional armies on the battle-field and neither was really able to keep pace with the changes in Europe. ${ }^{41}$ Therefore, the Ottoman achievement - facilitated by a series of devastating civil wars going on in Persia - did not lead to another war against the West as had happened previously following successful campaigns of the Prut and the Morea. Instead, the Ottoman victory in the East was taken with marked composure by Ottoman statesmen. Later on, however, Ibrahim Pasha mounted another major campaign led by the Sultan following a defeat of the Ottoman army in the East at the hands of an even less-modernised Persia. This loss resulted in an increase in food prices and taxes as well as a scarcity of food supplies in Ottoman society, and later became the catalyst for the tumultuous uprising in Istanbul named after its leader, the Patrona Rebellion in 1730s. This not only shattered Ottoman society, but also totally changed the Ottoman understanding of the world as we will see when examining in detail the third stage

${ }^{40}$ Even if Persia was not in a position to reciprocate Ottoman attacks at that time, Ahmed III could not help searching for alliances and looking for international consent for his actions (see Salzmann 2004, p. 39). In addition, Berkes argues that the reason why the Ottomans looked for intimate relations with the West throughout the 18th century was the newly emerging power of Russia in Eastern Europe (Berkes 1964, p. 24). In both cases, the unilateral policy of the 16th century was replaced with a diplomatic approach, taking advantage of peaceful solutions in lieu of wars in order to achieve imperial aims.

${ }^{41}$ Olson argues that just like the economy of Persia, the Ottoman economy in the 18th century which had lagged far behind the Christian West was unable to meet its imperial ambitions. This was the very reason for many significant conflicts that the empire experienced, and more importantly, it was introduced as a source for the exacerbation of tension among the Ottoman millets in the long run (Olson 1976-1977, p. 73). 
of the long 18 th century. ${ }^{42}$ Suffice it to say that the Patrona rebels, who had obtained the support of higher elite society (in particular members of the ulema), both deposed the Ottoman Sultan and killed the Grand Vizier Nevşehirli Ibrahim Pasha who had been de facto ruler of the Ottoman Empire after 1718. Thereby the newly emerged Muslim elites of the empire reached the apogee of their power and influence in history till that time at the expense of traditional rulers.

\section{Changing of Allegiance: The Sultan, Muslim and Non-Muslim Elites (1730-1750s)}

All these avenues that introduced a Western spirit into the Ottoman Empire came to an end with the eruption of the Patrona Rebellion in 1730, when Ahmed III was replaced by Mahmud I (1730-1754). This insurrection dramatically changed the Ottoman state structure, especially the balance and "redistribution of power" in favour of new Ottoman elites who came from different social and religious backgrounds. The decreasing emphasis on the sultan's role in government functions and the inability of the Ottoman dignitaries to protect their positions especially opened the way for some non-Muslim individuals in this third-stage development. It is particularly striking to note that out of the five sultans who reigned between 1648 and 1730, only Süleyman II (16871691) and Ahmed II (1691-1695) escaped from deposition, not to mention the number of Grand Viziers and highest Ottoman dignitaries who were often executed or, if they were lucky, expelled after their properties had been confiscated. What is more striking here is that all three Ottoman sultans who were either deposed or forced to abdicate the throne had to face up to their destiny following the imperial army's debacles against its enemies. ${ }^{43}$

Following the Patrona Rebellion of 1730, attempts to reform the traditional system of government with the help of western experience, and western skills such as introducing military training on the Janissaries were interrupted and even stopped (at least for a while). It did not put an end to the Ottoman westernisation, though. The new Sultan, Mahmud I, still added new military reforms to the old ones which had already proved ineffective and been far from putting the state on the right track. For instance, the French nobleman Comte Bonneval carried out some further military reforms with no noticeable results. He intended to reorganise the entire Ottoman army in the European style, but was faced with tremendous opposition either from the Janissaries and ulema, or foreign ambassadors during the decade following the rebellion of Patrona. The reason why Bonneval's efforts brought only limited success in spite of continuing

${ }^{42}$ As a contemporary eyewitness of the Patrona Rebellion, Abdi Efendi gives Ottoman defeats against the Persian as the stimulus for the rebels who were looking for the deposition and punishment of Grand Vizier İbrahim Pasha (Abdi Efendi 1943, pp. 25-29; see also Uzunçarşılı 1956, pp. 199-203; Aktepe 1958, pp. 89-102).

${ }^{43}$ Özkaya puts forward that first the failure of the second siege of Vienna in 1683 and then that of Iran following the Ottoman campaigns initiated in 1723 had a great influence on the development of ayans in the Ottoman Empire (Özkaya 1977, pp. 134-135). 
support from the Ottoman administration for western-inspired reforms is given as "lack of a determined and stable leadership that could sustain them in the face of strong popular opposition" (Levy 1982, p. 234).

The Patrona Rebellion of 1730 allowed a number of leading rebels and their immediate supporters to obtain some of the highest state offices. As a matter of fact, this rebellion had nothing to do with restoring the lost morality of Ottoman society or putting an end to extravagance and new forms of elite consumption which are often considered as the two most stimulating factors of all. Instead, it was an intra-elite struggle to transfer power and governance into the hands of another upper circle of bureaucracy, the ulema and the Janissaries (Karahasanoğlu 2009, pp. 9-16). However, Mahmud I was resolute enough to restore order to the capital first by eliminating the leader of the revolt, i.e. Halil and his comrades, then by re-establishing the authority of the state with the help of other interest groups within the empire. In other words, as Olson posits, it was none but the esnaf (artisans, skilled craftsmen) and merchants, having been the constant opponents of the sultan before, who now took the place of the ulema and the Janissaries in terms of supporting the sultan and his policies. In the spring of 1731, they came to aid the cause of the new Sultan, hoping to bring continuing disorder, which had so long threatened their business interests in Istanbul, to an end. This new allegiance between the Sultan and the esnaf, most of whom were non-Muslim, is presented as one of the most crucial changes which began to have an enormous effect in the reigns of Selim III (1789-1807) and Mahmud II (1808-1839) (Olson 19761977, p. 74). ${ }^{44}$

Before 1730 the Sultan's power essentially relied upon the elite members of the military class and the ulema. However, following the rebellion the military elite and the ulema started to collaborate with the anti-Sultan forces. Accordingly, they were against new European military techniques and did not like the idea of seeing European (basically called French in the documents) customs and ideas in Ottoman society. Even though ten years had passed since the suppression of the Patrona Rebellion, supporters of this uprising remained a potential menace to the Ottoman Sultan. It was during this time that the Sultan had to look for supporters other than the ulema and Janissaries who had jointly overthrown the former regime and were not inclined to support the new regime of Sultan Mahmud. Consequently, the Patrona Rebellion and its aftermath created a new era that gave rise to a realignment of the factions that either supported the Ottoman dynasty or opposed the new Sultan's policy of continuing relations with Europe. Olson puts forward that this reversal of support for the Sultan gradually brought about the centralisation of power in the hands of the Sultan in the late 18th and early 19th centuries (Olson 1974, p. 343). However, it is particularly important here to pose the question: who filled the gap of the military elite and the ule$m a$ who had essentially pulled the rug out from under the Sultan? Another question

${ }^{44}$ Abdi Efendi does not clearly say who had really fought for the Sultan on March 27, 1731 (Ramadan 17, 1143). All he is saying is that (other than members of the imperial army) citizens of Istanbul attacked the rebels as if it was a holy war (... şehirli umumen mezkûr haydutlar üzerine gayzay-l ekber niyetiyle ...) (Abdi Efendi 1943, p. 62). 
that also needs to be raised here is: what impact did this change have upon the Ottoman Empire and the Ottoman redistribution of power in the long run?

The first impact of this change of support in favour of the Sultan was increasing tension between Muslim and non-Muslim subjects of the empire. As a matter of fact, the tension between Muslim and non-Muslim artisans of the empire was not new. During the Tulip Era, when Ottoman integration into the world economy gathered strength, the main benefactor of this alteration seems to have been non-Muslim members of the guilds. As being more likely to speak European languages they were preferred by foreign agents. Tension between Muslims and non-Muslims became quite pronounced especially when the Ottomans started to experience difficulties in financing the wars against Iran and imposed more extraordinary campaign taxes. Before and after the uprising the ulema, who acted together with the rebels owing to economic and idealistic reasons, took the initiative and condemned not only Western ways of life, but also the non-Muslims, who became more and more associated with these "evils of the West". Unsurprisingly, soon this polarisation further damaged relations between the Muslim and non-Muslim subjects of the empire, especially those living in Istanbul (Barkey 2008, pp. 215-217).

The switch of allegiance of the esnaf to Mahmud I following the Patrona Rebellion is given as one of the most important changes of the era. In his dispatch dated 4/5 April 1731, the British ambassador in Istanbul Lord Kinnoull argued that the rebels "have made the Grand Signor stronger by showing the Janissaries that the merchants and tradesmen of the city will always be ready to join his favor unless he should make himself hated by some new impression". 45 The continuing Persian wars and the newly opened wars of 1736-1739 first against Russia and then Austria exacerbated the poor relations between the Sultan and the military class. Consequently, during the summer of 1740, another insurrection was initiated and some rebels in the capital began fighting in opposition to the government, just as it had happened a decade earlier. At this point, however, the Sultan was able to take advantage of his 1731 alignment with the esnaf who were armed to crush the rebellion on his order (Olson 19761977, p. 75).

As far as Subhî Mehmed Efendi is concerned, the crowds of esnaf were given no choice but to attack the insurgents if they wanted to keep themselves safe and sound. After all, with an imperial degree the Sultan ordered them to keep their shops open during the rebellion and attack and kill the troublemakers if need be. If they had ignored the orders, they would have been identified as rebels and punished accordingly. Consequently, some non-Muslim esnaf who had been armed by the Ottomans for the retaliation suppressed another attempted rebellion against the Sultan and helped the state to exterminate all of its participants. ${ }^{46}$ No matter what their reasons might have

${ }^{45}$ Quoted from Olson (1977, p. 192).

46 “ibtidâr iden mel'anetkârların bu def'a virilen fetvâ-yı şerîfe mûcibince demleri heder olduğuna binâen, her ne zamân zuhûr iderler ise cümle ittifâkıyla katlü i'dâmlarına ikdâm olunup, bir ferd dükkânını sedd ü bend itmemek ve her kim dükkânını kapamak sevdâsında olur ise eşkıyâyı merkûme ile ma'an ol dahi katl ü tedmîr olunup, hilâfina hareket idenlerin cezâ-yı sezâsı şer'an icrâ olunmak üzere sâdır olan hatt-ı hümâyûn-ı şevket-makrûn mûcibince tara taraf çarşu ve bâzâr 
been, taking arms against Muslims (even if they were rebels) further deteriorated the strained relations between the Muslims and non-Muslims (Olson 1977, pp. 195-198).

The story of the alliance between Mahmud I and his non-Muslim esnaf was also narrated by Sir James Porter approximately two decades later. Here, the story is a little different from what we find in the writings of Subhî. According to Porter's story, the non-Muslims (in his term Greeks) were neither armed by the Sultan nor given any choice but to attack the rebels. Instead, on account of their "ancient spirit" or desire for security, Greek shopkeepers did not refrain from attacking the rebels who had started to take the control of the whole city at that time. Namely, they took the initiative and murdered all Muslim rebels whom they caught with the only weapons that they had, i.e. poles. However, soon they were frightened due to having killed the "true believers" and sought asylum against any revenge that might come from coreligionists of dead Muslim rebels. Only at this juncture does co-operation between the Sul$\tan$ and the Greeks appear in Porter's writings. That is to say, due to his "equitability" the Sultan came to their help and did not let anyone to strike back at them. Instead, by means of getting a fetva (religious ruling) issued by a müfti (jurist counselor of Islamic law) the Sultan not only gave amnesty to the Greeks, but also fully sanctioned the execution of any troublemaker felt to be threatening individual security (Porter 1771, pp. 312-313).

Porter's explanation of the revolt of 1740 is of high importance in order to understand its impact upon the Ottoman Empire. That is, even about twenty years after the incident had really taken place, someone like Porter still found it noteworthy to record this incidence. First and foremost, this indicates that the revolt of 1740 and its suppression by the Sultan were not just mundane events. Instead, it is understood from Porter's writing that Ottoman citizenry of the $1760 \mathrm{~s}$ in Istanbul still remembered well what had happened in the 1740s and the way they interpreted it was not that different from the contemporary writings of Subhî at that time. Porter illuminated the conclusive impacts of this revolt upon Ottoman subjects, especially the non-Muslims, and how they interpreted their stand and position in the rebellion. On balance, starting with the revolt of the 1740s Porter's writing once again reminds us of the increasing power of the non-Muslims in general and the Greeks in particular.

Although similar social and economic conditions initiated the rebellion of 1730 and that of 1740, Sultan Mahmud seems to have learned much from his predecessors' mistakes and found a way to remain protected in the presence of danger resulting from the new insurgents in 1740. What is particularly important here is the fact that the non-Muslims had no choice but to throw their support in with the Sultan if they wanted to keep their property and prosper even further. After all, Mahmud I had a free hand to either protect or have them annihilated particularly after 1740. Accordingly, if they did not acknowledge and support his policies unconditionally, the Sultan could simply let them perish by turning the discontent of Muslim crowds on them. Consequently, the esnaf, who had been confronted with threats to their business and even their lives,

ve sâir esvâk $u$ mahallâtda münâdîler nidâ ve Bezzâzistan kethüdâsı ve sâir esnâf kethüdâlarına dahi ber-mûcib-i fermân-ı âlî gereği gibi tenbîh ü te'kîd olundu" (Subhî Mehmed 2007, p. 630). See also Şemdanizade Findıklılı Süleyman (1976, p. 97). 
became one of Mahmud's main bases of support during his reign. In return, the Sultan did not allow the non-Muslim millet (religious community) to suffer at the hands of the Muslim rebels in opposition to the social upheaval and revolt of 1730-1731, which had had a devastating impact upon the non-Muslim esnaf of the time. It was only through the nationalism of the early 19th century that the millet found a chance to free themselves from this contract which they got into in the 1740s (Olson 1976-1977, p. 76).

Non-Muslims as an alternative source of power to either members of the military class or those of the ulema need to be taken into consideration in every study of Ottoman history from the 1730s onwards. We have already mentioned how the Muslims who were not associated with the Ottoman military class found a chance to wield enormous influence over state economy and politics by means of the malikane system. Non-Muslim subjects of the empire did not seem to find much chance to take part in this system other than providing money for the entrepreneurs of the malikanes. ${ }^{47}$ Nevertheless, by taking the Sultan's side through supporting his policies, non-Muslims were now in the middle of the Ottoman decision-making process to determine the future of the empire. On balance, the realignment of 1731-1740 between Sultan Mahmud and his non-Muslim subjects as a mainstay of his reign changed the balance of power in favour of the non-Muslims for the first time.

\section{International Influence upon the Emergence of non-Muslim Elites}

Another turning point in the third stage of the 18th-century Ottoman Empire is Ottoman, Russian and Austrian Wars of 1736-1739. Russia declared another war against the Ottomans in April 1736 on the pretext of Tatar raids in Ukraine. Despite the initial successes of Russia in Crimea, neither the Ottomans nor the Russians were able to take full control of the region again. In the meantime, the Ottomans were also engaging in wars with Persia, since a treaty with Nadir Shah was not finalised until October 1737. Therefore, the Ottomans did their best not to face another Holy League that had led the empire into devastating defeats at the hands of Christian Europe more than fifty years earlier. At the outset, however, the worst happened because Austria decided to support Russia as an ally in January 1737. It was a time when the empire was simply not able to overpower either Russia in Crimea or Persia in the Caucasus. To be exact, the Ottomans did not really seem to be ready for a struggle against any of these powerful foes separately, let alone keeping wars going on in opposition to Russia, Austria and Persia at the same time throughout $1736-1737 .^{48}$

Quite unexpectedly, however, once again the Ottomans showed their strength to their two most formidable enemies of the 18th-century Ottoman Empire. That is, the

${ }^{47}$ Out of 1113 malikanes sold in the first three years after implementation, only five were bought by non-Muslims (Özvar 2003, p. 164).

${ }^{48}$ Unsurprisingly, from the very beginning of the war the empire was very eager to accept mediation and construct a peace with all of its formidable enemies. The imperial army launched a campaign against Russia on June 16, 1736 and only one day after this initial step, the Grand Vizier of the Ottoman Empire Mehmed Pasha sent a letter to both Britain and Holland begging for their mediation between the two opponent parties (Parvev 1995, p. 214). 
Ottomans' luck turned with the crushing victory scored against Austria. What is particularly important in this victory is that it was not the regular imperial army which brought the victory to the Ottomans. Instead, it was a local militia population who showed their strength and endurance against the enemies. ${ }^{49}$ Successful campaigns against the Habsburgs and then the Russians who were unable to follow their previous victories in the face of resolute Ottoman defenses, forced these enemies to accept the triumph of the Ottomans. By the Treaty of Belgrade signed in December 1739, the Ottomans not only gained Belgrade and the territories previously lost in the Treaty of Passarowitz, but also forced the Russians to sacrifice all their previous conquests other than Azov, which would also be razed to the ground and whose lands belonged to none. More importantly for our discussion, however, in return for French help and mediation, at the Treaty of Belgrade the Sultan bestowed France with trading privileges which not only allowed France to take full control of the Ottoman markets, ${ }^{50}$ but also gave a great opportunity to non-Muslim subjects of the empire who were now looking for more benefits from the state apparatus (Eldem 2006, pp. 319-321). We have already mentioned the political reversal of the non-Muslims who began supporting the Sultan after the 1730s. With the help of these capitulations the non-Muslims also began to gain the upper hand in Ottoman economy as well. Over time they became no less important than the Muslim ayan of the empire, who had already acquired political and economic powers following the first stages of the 18th century discussed above.

With the Treaty of Belgrade came a long period of peace on both the northern and the western frontiers of the empire, which would partly shape the fate of the empire leading up to the second half of the 18th century. An Ottoman-Iranian peace treaty was reached not too long after the Treaty of Belgrade in 1746, where a return to the border of 1639 was settled. Besides, from this point onwards Persia could not be regarded as a heretic state, always a good reason for the Ottomans to attack it previously. Instead, it was seen as another Orthodox Muslim state that needed to be a friend rather than an enemy (at least in the rhetoric) (see Finkel 2006, p. 364). ${ }^{51}$ Of further importance here is the fact that it had already been a long time since the Ottomans gave up their offensive campaign against opponents in the West. The Treaty of 1746 between

${ }^{49}$ To give an example, see Hekimoğlu Ali Pasha and his local army, in Aksan (2007, pp. $110-112$ ). Ottoman tenacity, which was mainly based on local militia, proved the fact that the empire had already tested the importance of local powers during the Morea Rebellion. Thus, it should not have been surprising to anyone that local powers were called back on the eve of the revolt of the 1770s. After all, they represented the last successful Ottoman resilience and resistance against two formidable opponents of the empire, and there is no doubt they might have been more successful against Russia in the 1770s as compared to soldiers of the imperial army. In conclusion, the Ottoman attempt to take advantage of the local armies which were mainly under the control of the newly emerged class, i.e. ayan, was not a new phenomenon by the time of the Morea Rebellion, and Muhsinzade Mehmed Pasha was just as determined to resort to them once again for the sake of a successful suppression of that rebellion when it arose.

${ }^{50}$ To understand the extent of the privileges that the Ottomans gave to France in 1740 and how they were interpreted from a contemporary account's point of view, see Vandal (1887, pp. $416-420)$.

${ }^{51}$ To understand the Ottoman justification of the wars against Persia in 1722, see Aktepe (1970, pp. 13-14). 
the Ottomans and Persians proved that the empire lost any further desire to make an attack in the East as well. It was a time when the Ottomans realised their limits of power and shaped a future policy and plan that did no longer include any aggressive action against their neighbours. Both in the West and in the East the best course the Ottomans could dream of was to keep the status quo intact and to avoid engagement in a fight or being a target of any of its opponents by using its already cultivated Ottoman diplomacy.

It is a fact that with the wars of 1736-1739 the Ottomans once again demonstrated their powers of endurance and eagerness to hold ground and even acquire some further gains when it was possible. However, unlike the years following the Treaty of Karlowitz it was now well known to anyone in Istanbul that the days of great expeditions had gone forever. Everyone in the empire longed for a sustained peace now. On the one hand, between 1699 and 1740 the Ottomans were able to score victories against all of their opponents including Russia, Venice, Iran and Austria. On the other hand, however, there were many devastating defeats that in the long run destroyed the Ottoman euphoric confidence generated by the victories that had been celebrated in the 15 th and 16th centuries. Both the Ottomans and their enemies were quite cognisant of the fact that Ottoman victory at the Treaty of Belgrade came not from the empire's own power but rather from international diplomacy, which took sides with a feeble Ottoman Empire against the increasing powers of Austria and Russia. As a result, the Ottomans not only relied to a greater extent on the diplomatic support of big powers, but also accepted this repulsive fact in opposition to the years immediately after the Treaty of Karlowitz. Otherwise, one cannot explain the lack of Ottoman hesitancy in signing the capitulations of 1740 with France. After all, throughout its long history the empire had never given such commercial privileges to any European state without actually getting anything in return (other than a fragile hope of further diplomatic support from France in the future). In other words, the empire agreed to give full commercial freedom to French merchants in their commercial activities in the Ottoman territories and perhaps more importantly, the Ottoman Sultan disclaimed their former right to abrogate this treaty forever. ${ }^{52}$ Indeed, throughout its long history the Ottoman Empire had also signed other treaties of capitulations with important European states such as England in 1675 and Holland in 1680. But not until 1740 did the Ottomans have to accept the status of its non-Muslim subjects as representatives of foreign consulates, which gave those non-Muslim subjects of the empire a unique status as we will shortly discuss in greater detail.

One of the most important effects of the French treaty of 1740 is that it provided a new opportunity to the non-Muslims subjects of the empire who were looking to enhance their power over other interest groups in the Ottoman Empire. It is a fact that the capitulations freed the hands of foreign traders who overcame local ones. Following the treaty Ottoman traders simply lost their competitive character and had no choice but to co-operate with the European traders. What is particularly important

${ }^{52}$ To get an idea of Ottoman policy of giving capitulations during its history, see Bağış (1998, pp. 1-18). 
here is the fact that it was largely the non-Muslim subjects of the empire who fully enjoyed this new opportunity. They not only became mediators between the foreign and the Muslim traders, but also gained full privileges of foreigners through acquiring the status of protégé, i.e. beratl, which had been previously granted only to dragomans and interpreters of foreign embassies. ${ }^{53}$ In the second half of the 18th century there was a huge demand for beratl status that not only put them on an equal footing with the foreign merchants, but also liberated them from any disadvantage that Ottoman subjugation would have been likely to impose upon them. In this respect, we have found many similarities between the malikane and beratl applications. Suffice it to say that both gave complete freedom and immunity to the new Muslim and non-Muslim elites of the empire from state intervention for a lifetime.

The non-Muslim subjects of the empire started to enjoy almost all benefits that had been exclusively given only to foreigners. For example, those who had berat did not have to pay haraç or cizye (poll-tax) nor were they subjected to other customary levies including extraordinary (avartz) and butchery taxes (kasabiye), non-canonical taxes such as tekalif-i örfiyye and masdariye. ${ }^{54}$ There is no doubt that the beratli subjects of the empire did their best to abuse their status and achieved exclusivity and protection that could have only been gained by bribing officials. What needs to be emphasised here is that the original intent of giving berat status to dragomans, who were supposed to facilitate commercial activities between Europeans in the Ottoman Empire, changed over time. Namely, owing to those enormous privileges bestowed on the beratlıs, foreign envoys of European states, who were free to employ anyone they liked as beratl, started to purchase berats for non-Muslim subjects of the empire (Bağiş 1998 , pp. 28-33). ${ }^{55}$ This created a substantial number of non-Muslims, who not only made a fortune out of this protected status, but were also keen on furthering their prosperity within the empire just like the Muslim ayan of the empire. ${ }^{56}$ Furthermore, they did not limit themselves to commercial gains that status of beratlı or hizmetkâr had opened, but they also took the chance on tapping other important sources of making themselves rich and acquiring prestigious positions in the empire. In other words, apart from working under the jurisdiction of the foreign ambassadors, beratll subjects of the Ottoman Empire became also kocabaşı (non-Muslim administrative leader) and

${ }^{53}$ At the outset, foreign states including Venice and France intended to cultivate people of their own origin who could manage Ottoman language and work as dragomans during their commercial activities with the Ottomans. However, soon it was understood that the best and cheapest way of communicating with the Ottomans was to use the Ottoman dragomans who were composed exclusively of non-Muslim citizens (Bağış 1998, pp. 25-27).

${ }^{54}$ For the tax exemption and huge privileges given to the dragomans including their sons and servants as well, see Boogert (2005, pp. 66-68).

${ }^{55}$ Boogert also accepts the fact that even if the empire had promised to let the foreign envoys choose whomever they wanted as beratll without any restrictions, it is only through the French capitulations of 1740 (art. 43) that "this privilege was universally applied" (Boogert 2005, p. 66).

${ }^{56}$ The number of dragomans who enjoyed these privileges throughout the whole empire is quite difficult to estimate. However, Boogert's study on ecnebi devletler defterleri offers us invaluable information at least concerning Great Britain, France and the Dutch Republic. His conclusion is worth mentioning here: in the course of the 18th century, not only did the number of protégés rise, but also the protection system spread steadily all over the empire (Boogert 2005, pp. 86-89). 
mütesellim (tax collector, deputy governor, local official), which made them essentially on a par with the Muslim local ayan of the 18th century (Bağış 1998, p. 40). The Ottoman attempt to issue imperial edicts to stop them from acting as ihtiyar (pir or şeyh of a guild), tax farmer or from taking part in local matters is a clear example of the earliest administrative measures against this trend (Bağış 1998, p. 108).

Another striking similarity between the beratlis and ayan that deserves mention here is that during the selection of prospective protégés, foreign embassies or consulates preferred the members of the same families they had employed before. As a result, although the post of beratl was not officially hereditary, in theory it evolved into a hereditary position that passed from father to son later known as the "dragoman dynasty" (Bağgş 1998, p. 84). Therefore, one can posit that such changes in the Ottoman system which had often been triggered by foreign interferences created ayan and beratlis (and later kocabassı) who could transfer these rights to their heirs without difficulty. Unsurprisingly, this made their power in the Ottoman Empire much more permanent, a development unheard of during the 16th and 17th centuries.

As the importance of the beratlis became clearer, Ottoman sources began to register beratlis and their servants by name in the second half of the 18th century. This should be seen as an Ottoman attempt to keep a tight rein on them so that they would not be easily able to abuse their positions at the expense of state interests (Bağış 1998, p. 97). However, one should keep in mind that it is not until Russia started to take full benefit of the capitulations that this system brought about a devastating impact upon the empire. And it was only at this juncture that the empire successfully created its own protection system against the misuses stemming from the beratl status. That is, even though Ottoman-Russian commercial relations began in the 15th century, they did not fully develop until the Treaty of Küçük Kaynarca in 1774. It was only then that Russia began to enjoy all the benefits that had already been given to other big powers of Europe. ${ }^{57}$ As we learn it from Boogert's studies, European states such as England and France did not actually like the idea of increasing the number of the protégés under their jurisdiction since they both interpreted it as a great danger to their own commercial privileges (Boogert 2005, pp. 97-102). ${ }^{58}$ Nonetheless, this was a great opportunity for the Russians and they took full advantage of it. In the end, it was not the European states but the Russians who in fact took the concept of communal protection as an important target and they got their chance from the Ottomans after the Treaty of Küçük Kaynarca (Boogert 2005, pp. 103-104). By the end of the 18th century, Zinkeisen argues, those who were under Russian protection as

${ }^{57}$ In fact, İnalc1k argues that there was a big difference between the capitulations given to Russia and other important European states. The former acquired these privileges as a result of a treaty that forced the empire to accept Russian demands. Previously, the Ottomans had been supposed to admit unilaterally the capitulations to be given to the European states, but now they had no choice but to accept Russian capitulations as a part of the Treaty of Küçük Kaynarca in 1774 (İnalc1k 2000, p. 250).

${ }^{58}$ Conversely, however, Masters makes a distinction between France and England in the way they approached the protégés. For example, in the case study of Aleppo, he posits that unlike England, France took full advantage of providing the non-Muslims with berats in order to increase its influence in the region (Masters 1988, pp. 96-97). 
protégés numbered as high as 200,000 people (Zinkeisen 1863 , p. 397 ). ${ }^{59}$ If this was actually the case, there is no doubt that the Russian style of distributing berats must have been quite distinct from that of other European states, but this is without doubt beyond the scope of this paper.

\section{Conclusion}

Following the Treaty of Karlowitz in 1699 and its aftermath the empire went bit by bit from hunter to the hunted in bloodthirsty struggles for power against overwhelmingly better organised enemy forces despite the fact that the Ottomans were still able to win victories long after the debacle of 1683-1699. The problems had been present since the second half of the 16th century, but it was only following the devastating Ottoman losses to Austria, Poland, Venice and Russia that these problems became a matter of life or death from the Ottoman statesmen's point of view. Although the Ottoman Empire had lost some crucial battles at the hands of both Christian Europe and Shi'i Persia long before the Treaty of Karlowitz, the empire never actually felt that such debacles were irreversible. Nonetheless, by the Treaty of Belgrade the Ottomans were totally convinced that there was no going back to the time of earlier centuries when the sense of the absolute superiority of their empire vis-à-vis the European states could be countenanced. In spite of gaining what had been lost at the Treaty of Passorowitz in 1718 and signing one of the most favourable treaties of the 18th century in 1739, the empire was now certainly aware of its weaknesses, limitations and vulnerabilities. Therefore, after 1699 the Ottomans simply abstained from conducting external relations within the earlier dichotomy of Dar ul-Islam (abode of Islam) versus Dar ul-Harb (abode of war) in practice. Following 1739, however, this was simply unsustainable even in rhetoric both in the East and the West. After all, this dichotomy required a permanent state of war against the infidels living outside the borders of the empire which the empire could neither afford nor dare to follow any longer, especially in the second half of the 18th century. The Ottomans from time to time tested their strength and ability in acquiring the huge territories that had been previously lost to foreign powers as well as gaining further lands for the sake of the Dar-ul Islam. At the end of this process of measuring its strength and endurance the Ottoman Empire not only integrated into the diplomatic system of Europe over time, but also seemed preoccupied with adopting a peace-seeking policy for the rest of the 18 th century. ${ }^{60}$

At this stage the loss of huge territories, especially in the Balkan, did not really prevent the Ottoman state from reasserting itself as a major world power and reorganising its traditional institutions. On the contrary, the Ottomans not only succeeded in surviving devastating impacts of the long lasting wars and the crises thereafter, but also in changing dramatically its traditional structure to meet the demands of the new

\footnotetext{
${ }^{59}$ Rey also accepts that in violation of the capitulations, Russia started to abuse the beratl status following the Treaty of Küçük Kaynarca in 1774 (Rey 1899).

${ }^{60}$ To understand the Ottoman attitude towards Christian Europe in the 18th century, see Yurdusev (2004, pp. 5-35).
} 
external environment and conditions of the later centuries. This meant incredible economic and financial burdens on the Ottoman budget, which only became bearable through the transformation of the landholding and military systems of the empire and the decentralisation of its urban and provincial administration. Willy-nilly these changes opened the way for the emergence of Muslim (members of pasha households, ayan, malikane owners etc.) and non-Muslim (Phanariotes, dragomans, beratlls etc.) elites at the expense of the central authority and the Ottoman sultans' power. Although each elite group had its own unique history of gaining power and influence, they all not only firmly established their power in course of this time, but also they already became indispensable figures of the Ottoman Empire by the 1750s whose power and influence always needed to be taken into consideration. Given much greater autonomy and freed from the tight control of central authorities, members of these new elites were not only more concerned about their influence in the empire, but also had means and more stable power bases to acquire further gains from this newly created Ottoman system. This proliferation of power bases (both at the local level and in the central state) was the result of a long process of consolidation of power that had been stimulated as a result of three distinct eras outlined in this paper. In the acquisition of economic and political power the state lost its early monopoly and right to distribute the power to whomever it wanted. As a result, in the decades following the Treaty of Karlowitz Ottoman sultans more and more lost their invulnerable and authoritative position of command, since they could no longer play the role of the benefactor who had earlier provided protection, arms, provisions and booty to members of their military bureaucracy (Christensen 1990). By the end of these three stages the Muslim and non-Muslim elites of the state were less and less dependent on the sultans for maintaining their positions and more and more willing and able to make decisions in conflict with (or even against) the central state.

Last but not least, the period between 1683 and the 1750s is an era of transition from a single sovereignty of the sultan to multiple sovereignties of first Muslim and then non-Muslim notable figures. ${ }^{61}$ By and large, these new elites and their mostly biological successors of the late 18th and early 19th centuries started to dominate the empire from the last quarter of the 18th century. Even though we cannot immediately associate the emergence of these new groups in Ottoman society with their religious, ethnic or national backgrounds, Ottoman classification of the millet system, based on a person's belonging to a religious community, played a determining role in each having had to take a different development path to reach the same ends during the period

${ }^{61}$ Tezcan makes a clear distinction between Muslim and non-Muslim subjects of the empire by relying on the term reaya which, according to him, started to gain a different connotation in the 18th century. That is, unlike in previous centuries when this term had been used for Ottoman subjects of peasants in general, from the 18th century onwards the term reaya more and more referred to non-Muslim (Christian) subjects of the empire. The first-class Muslim subjects of the empire, who came to be exclusively associated with the ruling strata, step by step shared a common/superior identity, to some extent identical to the "white settlers in colonial America". Unlike Indians and Africans, however, it was not the "race" of the reaya, but rather their non-Islamic religions which left them behind on their way to occupy more prestigious positions in the 18th-century Ottoman society (Tezcan 2010, pp. 235-236). 
under discussion. Nonetheless, the Ottoman millet system falls far short of understanding this new class and their relation with the state once they got the power in their hands. To be exact, neither the new Muslim nor non-Muslim elites of the empire looked forward to establishing their own autonomous or independent states of liberation from the "Turkish yoke". Instead, they did enthusiastically pursue their own personal interests and motivations which did not necessarily cope well with their religious and national/ethnic ideology or set of beliefs in order to take action in opposition to what is often claimed in the secondary literature of the time at issue. ${ }^{62}$ At least another half a century had to pass so that someone could reasonably posit that co-operation between Muslim and non-Muslim subjects of the empire largely disappeared and each Ottoman elite systematically looked for nothing but a total destruction of the Ottoman authority in the lands under their influence or direct control.

\section{References}

Abdi Efendi (1943): 1730 Patrona İhtilâli Hakkında Bir Eser: Abdi Tarihi. Edited by Faik Reşit Unat. Ankara, Türk Tarih Kurumu Basımevi.

Abou-El-Haj, Rifaat Ali (1974): The Ottoman Vezir and Paşa Households 1683-1703: A Preliminary Report. JAOS Vol. 94, (Oct.-Dec.), pp. 438-447.

Abou-El-Haj, Rifaat Ali (1984): The 1703 Rebellion and the Structure of Ottoman Politics. Leiden, Nederlands Historisch-Archaeologisch Instituutte (Istanbul).

Ahmet Cevdet (1858-1883): Tarih-i Cevdet, Vol. 1. Istanbul, Osmanl1 Matbaas1.

Akdağ, Mustafa (1970-1974): Osmanlı Tarihinde Ayanlık Düzeni Devri 1730-1839. DTCF Tarih Araştırmaları Dergisi Vols 8-12, pp. 51-61.

Aksan, Virginia H. (2007): Ottoman Wars 1700-1870: An Empire Besieged. Harlow, Longman/Pearson.

Aktepe, Münir (1958): Patrona İsyanı (1730). Istanbul, Edebiyat Fakültesi Basımevi.

Aktepe, Münir (1970): 1720-1724 Osmanl-İran Münâsebetleri ve Silâhşör Kemânî Mustafa Ăga'nın Revân Fetih-Nâmesi. Istanbul, Istanbul Universitesi Edebiyat Fakültesi.

Bağış, Ali İhsan (1998): Osmanlı Ticaretinde Gayri Müslimler. Ankara, Turhan Kitabevi Yayınları.

Barkey, Karen (2008): Empire of Difference: The Ottomans in Comparative Perspective. Cambridge-New York, Cambridge University Press.

Belin, M. (1864): Essais sur l'histoire économique de la Turquie. Paris, Imprimerie Impériale.

Berkes, Niyazi (1964): The Development of Secularism in Turkey. Montreal, McGill University Press.

Boogert, Maurits H. van den (2005): The Capitulations and the Ottoman Legal System: Qadis, Consuls, and Beratls in the 18th Century. Leiden-Boston, Brill.

Brue, Benjamin (1870): Journal de la campagne que le grand vesir Ali Pacha à faite en 1715 pour la conquête de la Morée, Paris, Ernest Thorin.

Cezar, Mustafa (1965): Osmanlı Tarihinde Levendler. Istanbul, Çelikcilt Matbaası.

Cezar, Yavuz (1986): Osmanlı Maliyesinde Bunalım ve Değişim Dönemi: Xviii. Yy'dan Tanzimata Mali Tarihi. Istanbul, Alan Yayınc1lı.

${ }^{62}$ To give but one example, see Gündoğdu's article focusing chiefly on the second half of the 18th-century Ottoman Empire (Gündoğdu 2014). 
Christensen, Stephen T. (1990): Violence and the Absolutist State: Studies in European and Ottoman History. Copenhagen, Akad. Forl.

Davies, Siriol (2007): Between Venice and Istanbul: Colonial Landscapes in Early Modern Greece. Princeton, American School of Classical Studies at Athens.

Dukes, Paul (1990): The Making of Russian Absolutism 1613-1801. London-New York, Longman.

Dutu, Alexandru-Cernovodeanu, Paul (eds) (1973): Dimitrie Cantemir. Bucharest, Association internationale d'études du sud-est européen.

Eldem, Edhem (1998): Osmanlı Devleti ve Fransa: 17. ve 18. Yüzy1llarda Devlet-Ekonomi İlişkilerine Karşılaştırmalı Bir Bakış. In: Hamdi Can Tuncer (ed.): Osmanlı'dan Cumhuriyet'e Problemler, Araştırmalar, Tartışmalar. Istanbul, Tarih Vakfı Yurt Yayınları, pp. 14-32.

Eldem, Edhem (2006): Capitulations and Western Trade. In: Faroqhi, Suraiya (ed.): The Cambridge History of Turkey. Cambridge-New York, Cambridge University Press, Vol. 3, pp. 283-335.

Erdenen, Orhan (2003): Lâle Devri ve Yansımaları. Istanbul, Türk Dünyası Araştırmaları Vakfi.

Ertaş, Mehmet Yaşar (2007): Sultanın Ordusu: Mora Fethi Örneği 1714-1716. Istanbul, Yeditepe.

Finkel, Caroline (2006): Osman's Dream: The Story of the Ottoman Empire, 1300-1923. New York, Basic Books.

Genç, Mehmet (2002): Osmanlı Maliyesinde Malikane Sistemi. In his Osmanlı Imparatorluğunda Devlet ve Ekonomi. Istanbul, Ötügen, pp. 99-152.

Gündoğdu, Birol (2014): A Boiling Cauldron of Conflicts and Cooperation: The Question of Two Distinct Societies during and after the Morea Rebellion of 1770. International Journal of Turkish Studies Vol. 20, pp. 67-84.

İnalcık, Halil (1977): Centralization and Decentralization in Ottoman Administration. In: Naff, Thomas - Owen, Roger (eds): Studies in Eighteenth-Century Islamic History. Carbondale, Southern Illinois University Press, pp. $27-52$.

İnalcık, Halil (1980): Military and Fiscal Transformation in the Ottoman Empire. Archivum Ottomanicum Vol. 6, pp. 283-337.

İnalcık, Halil (1983): The Emergence of Big Farms, Çiftliks: State, Landlords and Tenants. In: Dumont Bacqué-Grammont, Paul Jean-Louis (ed.): Contributions à l'histoire économique et sociale de l'Empire Ottoman. Leuven, Peeters, pp. 105-126.

İnalcık, Halil (2000): İmtiyâzât. In: Topaloğlu, Bekir-Erünsal, İsmail E. -Özel, Ahmet (eds): Türkiye Diyanet Vakfi İslâm Ansiklopedisi. Istanbul, Divantaş, Vol. 22, pp. 245-252.

Karahasanoğlu, Selim (2009): Politics and Governance in the Ottoman Empire: The Rebellion of 1730. Cambridge, Harvard University.

Kaymaz, Nejat (2002): Kuruluştan 'Lale Devri’ne Osmanlı Imparatorluğu: Çıplak Gözün Gördükleri. Istanbul, Kaynak Yayınları.

Kiel, Machiel (2007): The Smaller Aegean Islands in the 16th-18th Centuries according to Ottoman Administrative Documents. In: Davies, Siriol (ed.): Between Venice and Istanbul. Athens, The American School of Classical Studies, pp. 35-54.

Küçük Çelebizade Asım (1865): Tarih-i Çelebizade: Küçük Çelebizade. Istanbul, Matbaa-i Âmire.

Kurat, Akdes Nimet (1951): Prut Seferi ve Barlşı, 1123 (1711). Ankara, Türk Tarih Kurumu Basımevi.

Leon, George B. (1972): The Greek Merchant Marine (1453-1850). In: Papadopoulos, Stelios A. (ed.): The Greek Merchant Marine (1453-1850). Athens, National Bank of Greece.

Levy, Avigdor (1982): Military Reform and the Problem of Centralization in the Ottoman Empire in the Eighteenth Century. Middle Eastern Studies Vol. 18, No. 3, pp. 227-249.

Lewis, Bernard (2002): What Went Wrong? New York, Oxford University Press.

Masters, Bruce (1988): The Origins of Western Economic Dominance in the Middle East: Mercantilism and the Islamic Economy in Aleppo, 1600-1750. New York, New York University Press (New York University Studies in near Eastern Civilization). 
Masters, Bruce (2006): Christians in a Changing World. In: Faroqhi, Suraiya (ed.): The Cambridge History of Turkey. Volume 3: The Later Ottoman Empire, 1603-1839. Cambridge, Cambridge University Press, pp. 272-281.

McGowan, Bruce (1994): The Age of the Ayans, 1699-1812. In: İnalcık, Halil-Quataert, Donald (eds): An Economic and Social History of the Ottoman Empire 1300-1914. Cambridge, Cambridge University Press.

Mehmed Raşid (1865): Tarih-i Raşid. Vol. 4. Istanbul, Istanbul Matbaa-1 Amire.

Mert, Özcan (1991): Âyan. In: Topaloğlu, Bekir-Özel, Ahmet-Akün, Ömer Faruk (eds): Diyanet Íslam Ansiklopedisi (Istanbul). Vol. 4, pp. 195-198.

Motraye, Aubry de La (1723): A. De La Motraye's Travels through Europe, Asia, and into Part of Africa. Vol. 1. London, A La Haye.

Olson, Robert W. (1974): The Esnaf and the Patrona Halil Rebellion of 1730: A Realignment in Ottoman Politics? Journal of the Economic and Social History of the Orient Vol. 17, No. 3, pp. 329-344.

Olson, Robert W. (1976-1977): The Ottoman Empire in the Middle of the Eighteenth Century and the Fragmentation of Tradition: Relations of Nationalities (Millets), Guilds (Esnaf) and the Sultan, 1740-1768. Die Welt des Islam Vol. 17, pp. 72-77.

Olson, Robert W. (1977): Jews, Janissaries, Esnaf and the Revolt of 1740 in Istanbul: Social Upheaval and Political Realignment in the Ottoman Empire. Journal of the Economic and Social History of the Orient Vol. 20, No. 2, pp. 185-207.

Özkaya, Yücel (1977): Osmanlı İmparatorluğunda Ayânlık. Ankara, Türk Tarih Kurumu.

Özvar, Erol (2003): Osmanlı Maliyesinde Malikâne Uygulaması. Istanbul, Kitabevi.

Pamuk, Şevket (2004): Institutional Change and the Longevity of the Ottoman Empire, 1500-1800. Journal of Interdisciplinary History Vol. 35, No. 2 (Autumn), pp. 225-247.

Parvev, Ivan (1995): Habsburgs and Ottomans between Vienna and Belgrade (1683-1739). New York, Boulder, Distributed by Columbia University Press (East European Monographs 431).

Philliou, Christine M. (2004): Worlds, Old and New: Phanariot Networks and the Remaking of Ottoman Governance in the First Half of the Nineteenth Century. PhD dissertration, Princeton University.

Philliou, Christine M. (2009): Communities on the Verge: Unraveling the Phanariot Ascendancy in Ottoman Governance. Comparative Studies in Society and History Vol. 51, No. 1, pp. 151181.

Porter, Sir James (1711): Observations on the Religion, Law, Government, and Manners of the Turks. London, J. Nourse.

Quataert, Donald (2005): The Ottoman Empire: 1700-1922. New York, Cambridge University Press.

Rey, Francis (1899): La protection diplomatique et consulaire dans les echelles du Levant et de Barbarie: avec des documents inédits. Paris, Larose.

Roider, Karl A. (1982): Austria's Eastern Question, 1700-1790. Princeton, Princeton University Press.

Sadat, Deena R. (1972): Rumeli Ayanları: The Eighteenth Century. The Journal of Modern History Vol. 44 (September), pp. 346-363.

Sahillioğlu, Halil (1999): The Income and the Expenditure of the Ottoman Treasury between 1683 and 1740. In his Studies on Ottoman Economic and Social History. Istanbul, Research Center for Islamic History, Art and Culture, pp. 65-89.

Şahin, Canay (2005): The Economic Power of Anatolian Ayans in the Late Eighteenth Century, the Case of the Caniklizades. International Journal of Turkish Studies Vol. 11, pp. 29-48. 
Salzmann, Ariel (1993): An Ancient Regime Revisited: Privatization and Political Economy in the 18th Century Ottoman Empire. Politics \& Society Vol. 21 (December), pp. 393-423.

Salzmann, Ariel (2004): Tocqueville in the Ottoman Empire: Rival Paths to the Modern State. Boston, Brill.

Salzmann, Ariel (forthcoming): Centripetal Decentralization: Life-Term Taxfarming in the 18th Century in the Ottoman Empire. In: Tosum Aracanli - Ashraf Ghani - David Ludden (eds): Political Economies of the Ottoman, Safavid and Mogul Empires, Vol. 1.

Şemdanizade Fındıklılı Süleyman (1976): Şemdanizade Fındıklılı Süleyman Efendi Tarihi Mürit Tevarih 1. Transl. M. Münir Aktepe. Istanbul, Edebiyat Fakültesi Matbaası.

Silahdar Fındıklı Mehmet (1969): Nusretnâme. Vol. 2/2. Edited by İsmet Parmaksızoğlu. Istanbul, Milli Egitim Basımevi.

Sözen, Zeynep (2000): Fenerli Beyler: 110 Yllın Öyküsü, 1711-1811. Istanbul, Aybay Yayınc1lı.

Stoianovich, Traian (1963): The Social Foundations of Balkan Politics, 1750-1941. In: Jelavich, Charles - Jelavich, Barbara (eds.): The Balkans in Transition; Essays on the Development of Balkan Life and Politics since the Eighteenth Century. Berkeley, University of California Press, pp. 297-345.

Subhî Mehmed (2007): Subhî Tarihi: Sâmi ve Şâkir Tarihleri İle Birlikte. Edited by Mesut Aydıner. Istanbul, Kitabevi.

Suceska, Avdo (1985): Mâlikâne. İstanbul Üniversitesi İktisat Fakültesi Mecmuası Vol. 41, pp. $261-282$.

Sutton, Robert (1953): The Despatches of Sir Robert Sutton, Ambassador in Constantinople (17101714). Edited by Akdes Nimet Kurat. London, The Royal Historical Society.

Tezcan, Baki (2010): The Second Ottoman Empire: Political and Social Transformation in the Early Modern World. New York, Cambridge University Press.

Trypanis, C. A. (1963): Greek Literature since the Fall of Constantinople in 1453. In: Jelavich, Charles - Jelavich, Barbara (eds.): The Balkans in Transition; Essays on the Development of Balkan Life and Politics since the Eighteenth Century. Berkeley, University of California Press, pp. 227-257.

Uzunçarşılı, İsmail Hakkı (1944): Âyân. In: İslâm Ansiklopedisi. Istanbul, Maarif Matbaası, Vol. 2, pp. 40-42.

Uzunçarş1l1, İsmail Hakkı (1956): Osmanlı Tarihi. Vol. 4/1. Ankara, Türk Tarih Kurumu Basımevi.

Vandal, Albert (1887): Une ambassade française en Orient sous Louis XV: La mission du Marquis de Villeneuve, 1728-1741. Paris, E. Plon, Nourrit et Cie.

Wheatcroft, Andrew (2009): The Enemy at the Gate: Habsburgs, Ottomans and the Battle for Europe. New York, Basic Books.

Yıldız, Hakan (2006): Haydi Osmanlı Sefere! Prut Seferi'nde Organizasyon ve Lojistik. Istanbul, Türkiye İş Bankası Kültür Yayınları.

Yirmisekiz Çelebi Mehmed (1993): Yirmisekiz Çelebi Mehmed Efendi'nin Fransa Sefâretnâmesi. Edited by Beynun Akyavaş. Ankara, Türk Kültürünü Araştırma Enstitüsü.

Yurdusev, Nuri (2004): The Ottoman Attitude toward Diplomacy. In: Yurdusev, Nuri (ed.): Ottoman Diplomacy: Conventional or Unconventional? Basingstoke, Hampshire-New York, Palgrave-Macmillan, pp. 5-35.

Zarinebaf, Fariba (2005): Soldiers into Tax-Farmers and Reaya into Sharecroppers: The Ottoman Morea in the Early Modern Period. In: Zarinebaf, Fariba-Bennet, John-Davis, Jack L. (eds): An Historical and Economic Geography of Ottoman Greece: The Southwestern Morea in the 18th Century. Athens, American School of Classical Studies at Athens.

Zinkeisen, Johann Wilhelm (1863): Geschichte des Osmanischen Reiches in Europa. Vol. 7. Hamburg, F. Perthes. 